\title{
Antakya Şehri ve Yakın Çevresinde Rekreasyon Faaliyetlerinin Özellikleri ve Dağılışı
}

\section{Characteristics and Distribution of Recreative Activities in the City of Antakya and Its Surroundings}

\author{
Hüsniye DOLDUR ${ }^{1}$ [D, Öznur NESİPOĞLU ${ }^{1}$ [D \\ 'İstanbul Üniversitesi, Edebiyat Fakültesi, Coğrafya Bölümü, İstanbul, Türkiye
}

ORCID: H.D. 0000-0002-3984-7298; Ö.N. 0000-0003-2249-768X

\section{ÖZ}

Endüstrileşme, yarattığı iş olanaklarıyla 19. yüzyılın başlarından itibaren dünyanın kırsal bölgelerindeki işsiz nüfusun şehirlere göç etmesini hızlandıran bir faktör olmuştur. Endüstriyel üretim faaliyetlerinin yaygınlaşmasıyla daha çok insan şehirlere göç etmiş ve pek çok sorun ortaya çıkmıştır. Bu sorunlara üretim ve çalışma koşullarındaki zorluklar da eklenince, insanın dinlenme ve kendini yenileme ihtiyacı ortaya çıkmıştır. Bu doğrultuda biyo-psikososyal bir varlık olarak insanın "tazelenme", "dinlenme" ve "eğlenme" gibi gereksinimlerini karşılamaya yönelik olarak şehirlerde rekreasyon faaliyetleri geliştirilmeye başlanmıştır.

Türkiye'de de rekreasyon faaliyetlerinin geliştirilmesine yönelik çalışmalar çok önceleri başlatılmış olsa da, bu alandaki asıl gelişmeler şehirleşmenin hız kazandığı 1950 sonrasında olmuştur. Bu çalışmada Antakya şehri ve yakın çevresindeki rekreasyon faaliyetlerinin özellikleri ve dağılışı incelenmiştir. Çalışmanın temel veri kaynaklarını ilgili kamu kuruluşlarının hazırladığı rapor ve istatistikler, basılı ve görsel kaynaklar, literatür araştırması ve arazi çalışmaları oluşturmaktadır. Ayrıca AutoCAD ve CorelDRAW programları kullanılarak şehirdeki rekreasyon faaliyetlerinin dağılışını gösteren harita oluşturulmuştur.

Anahtar kelimeler: Türkiye, Antakya, Rekreasyon, Turizm

\section{ABSTRACT}

With the job opportunities it has created since the beginning of the 19th century, industrialization has been an effective factor in the migration of unemployed people to cities from rural regions worldwide. As industrial production activities have spread, more people have migrated to urban areas and, in turn, the rapidly increasing population began to cause problems in the cities. In addition to the problem mentioned above, difficulties in production and poor working conditions have given rise to the need for workers to have opportunities of rest and self-renewal. As it is, recreational activities have started to develop in the cities.

Although efforts for the development of recreational activities in Turkey started a long time ago, essential developments in this field occurred after the 1950 s when urbanization gained speed. This article studies the characteristics and distribution of the recreational activities in the city of Antakya. The main data sources of the study consist of reports and statistics issued by public institutions as well as printed and visual references and land surveys.

Keywords: Turkey, Antakya Province, Recreation, Tourism

Başvuru/Submitted: 13.03.2021 • Revizyon Talebi/Revision Requested: 28.05.2021 • Son Revizyon/Last Revision Received: 25.08 .2021 • Kabul/Accepted: 24.01.2022 - Published Online/Online Yayın: 15.02 .2022

Sorumlu yazar/Corresponding author: Hüsniye DOLDUR / hdoldur@istanbul.edu.tr Atıf/Citation: Doldur, H., \& Nesipoglu, O. (2022). Antakya şehri ve yakın çevresinde rekreasyon faaliyetlerinin özellikleri ve dağılışı. Cografya Dergisi. Advanced online publication. https://doi.org/10.26650/JGEOG2021-896150 


\section{EXTENDED ABSTRACT}

\section{Introduction}

With the job opportunities it has created since the beginning of $19^{\text {th }}$ century, industrialization has been an effective factor in the migration of unemployed people to cities from rural regions worldwide. Upon the spread of industrial production activities, more people migrated to cities and, in turn, the rapidly increasing population caused problems in those cities such as traffic, noise and environmental pollution, and thus city life became difficult for people. In addition to the difficulties mentioned above, other problems such as the production and working conditions that workers endure have resulted in the need for workers to rest and find time for self-renewal. As it is, recreational activities have started to develop in many cities in order to meet the requirements of people as a bio-psychosocial beings for whom "refreshment", "resting" and "entertainment" are important. Recreational sites which urban people need are being developed in many cities, large and small, today. Although efforts for the development of recreational activities in Turkey started a long time ago, essential developments in this field occurred after the 1950s when urbanization gained speed. With the spread of industrial activities after 1950, migration from the rural areas to the cities accelerated, resulting in the increased population of the cities. In order to meet the needs of rest and entertainment for the increased population, recreational activities started to be developed in the cities.

\section{Data and Method}

This article studies the characteristics and distribution of the recreational activities in the city of Antakya including its vicinities, which has hosted different civilizations throughout history and which intends to reveal its potential to create new recreational areas. The main data sources of the study consist of reports and statistics issued by public institutions, as well as printed and visual references and land surveys.

\section{Conclusion}

Located on important trade routes and having hosted a number of civilizations throughout history, Antakya is a rich city in terms of history and cultural characteristics. This richness is a resource for the development of recreational activities in the city. Most important among these resources are the historical structures which have survived from past civilizations. Many of these buildings (Ulu Mosque, Habib-i Neccar Mosque, the Long Bazaar, Antakya Synagogue, the Catholic Church, the Orthodox Church, St. Pierre Church and Antakya houses with their traditional architecture, etc.) are used for recreational purpose to serve the city people. However, our study showed that some historical assets of the city are not used in this respect.

Another indicator of the cultural richness of Antakya is its traditional cuisine with its 600 specialties bearing trace of the dominant civilizations in the past. The traditional Antakya cuisine was registered by UNESCO in 2017 and the city was recognized as the " $26^{\text {th }}$ Gastronomy City of the World". Endowed with this title, Antakya has obtained an important chance to become one of the most significant centres for gastronomy both in Turkey and the world. In order to take advantage of this opportunity, the necessary arrangements should be made for introduction of the city's cuisine culture into food festivals, food tours, local bazaars, and cooking workshops, and effort should be made to make Antakya a world-class gastronomy centre.

In addition to its historical and cultural resources, Antakya has great potential in terms of natural resources (forests, the River Asi, Harbiye Falls, etc.) for development of recreational activities. Natural woodland in and around the city are used to meet the recreational needs of the city people by means of many parklands and picnic areas. Among the natural resources of the city is the River Asi. However, the river is not sufficiently used for recreation. In fact, the use of the river as a place for organizing water sports and recreational units along the river banks would breathe new life into the recreational life of the city. Harbiye Falls are one of the natural resources of the city and these are situated close to the centre. Although the location of the falls is used for recreational purposes, the arbitrary distribution of the organizations providing food and other services (restaurants, cafes, stores selling local souvenirs) creates such chaos that it impairs the appearance of the falls. This situation should be controlled by means of new environmental planning, paying attention to the preservation of local natural characteristics. 


\section{GİRIŞ}

Sanayileşme ve şehirleşme, insana ve ürettiklerine yüklenen anlamı olduğu kadar, insanın "kendini gerçekleştirme" anlayışını da etkilemiş ve boş zamanlarında rekreasyon faaliyetlerine yönelik farkındalığını arttırmıştır. Şehir insanı günlük yaşamın tekdüzeliğinden kurtulmak amacıyla "boş zaman" olarak adlandırılan ve yaşamın zorunlulukları dışında kalan zamanını değerlendirmek için rekreasyon faaliyetlerine gereksinim duymuştur. İhtiyaç duyduğu bu faaliyetlerin kendisine yakın alanlarda bulunması ise son derece önemli olmuştur (Sevil, 2012; Özgüç, 2017).

Rekreasyon, sözcük anlamı olarak "yenilemek", "düzenlemek", "tazelemek", , "eğlendirmek" ve "dinlenmek" anlamlarını içermektedir. Sözcük anlamıyla bağlantılı olarak rekreasyon; İnsanların, varoluş (uyuma-yeme-içme vb.) ve çalışma (işe gidiş-geliş, çocuklar için okul, kadınlar için ev işleri vb.) için gerekli olanın dışındaki tüm zamanlar olarak tanımlanan boş zamanlarında yaptıkları faaliyetleri ifade eden bir kavramdır (Sevil, 2012; Özgüç, 2017).

Rekreasyon faaliyetleri hem şehirlerde hem de şehre yakın kırsal alanlarda gerçekleştirilebilmektedir. Şehirlerdeki rekreasyon faaliyetleri, sinema, tiyatro, eğlence merkezi, kültür ve sanat merkezi, park ve hayvanat bahçesi gibi farklı nitelikteki kapalı ve açık alanlarda gerçekleştirilebilmektedir. Kırsal rekreasyon faaliyetleri olarak adlandırılan faaliyetler ise özünde "kırsal" kökenli olmayıp, kökenini şehirde gerçekleştirilen faaliyetlerden almış, ancak geniş arazi kullanımı ve bazı doğal unsurları gerektirmesi nedeniyle "kırsal" olarak nitelendirilen "açık hava" faaliyetlerini içermektedir. Bölgesel ölçekteki parklar, özel çiftlikler, koruluklar, boş kıyılar, hayvanat bahçeleri, botanik bahçeleri, yapay kanallar, baraj gölleri, hatta bahsi geçen alanlar arasında yer almayan boş kırsal alanlar, "kırsal rekreasyon faaliyet" alanlarına örnek teşkil etmektedir (Özgüç, 2011;Şimşek, 2012).

Sanayileşme ve şehirleşmenin yarattığı yeni yaşam şekli, insanlara kendilerine ayıracakları boş zamanlar yaratınca, insanların bu zamanlarını değerlendirebilmeleri (dinlenme, eğlenme, hoşça vakit geçirme vb.) için dünyanın neredeyse bütün şehirlerinde rekreasyon alanları oluşturulmaya başlandı. Türkiye'de de rekreasyon faaliyetlerinin geliştirilmesine yönelik çalışmalar çok önceleri başlatılmış olsa da, bu alandaki asıl gelişmeler şehirleşmenin hız kazandı $\mathrm{g} 11950$ sonrasında olmuştur (Şimşek, 2012). 1950 sonrası Türkiye'de sanayi faaliyetlerinin yaygınlaşmasıyla kırlardan şehirlere olan göç hareketi hızlanmış ve şehirlerin nüfusları kısa sürede artmıştır (Tümertekin, 1968). Artan nüfusun dinlenme ve eğlenme ihtiyaçlarını karşılamak üzere şehirlerde rekreasyon faaliyetleri geliştirilmeye başlanmıştır. Önceleri büyük şehirlerde başlayan bu faaliyetler, daha sonra diğer şehirlerde de yayılmıştır.

Rekreasyon faaliyetlerinin Türkiye şehirlerinin mekânsal kullanımlarında yarattıkları değişiklikler coğrafyacıların da ilgisini çekmiş ve yakın yıllarda bu alanda pek çok çalışma yapılmıştır. Bu çalışmalardan bazılarını şu şekilde sıralayabiliriz; (Timor, 2004), (Kaçmaz, 2005), (Doldur, 2011ve 2014), (Garipağaoğlu ve Uzun, 2014), (Çavuş, 2014), (Kaçmaz ve Döker, 2014), (Kartal, 2015), (Sandal ve Karademir, 2015), (Kapan, 2016 ve 2018), (Ilgar ve Şeran, 2019) ve (Ceylan ve Bulut, 2019).

Bu makalede tarih boyunca pek çok medeniyete ev sahipliği yapmış Antakya Şehri ve yakın çevresindeki rekreasyon faaliyetlerinin özellikleri ve dağılışı ele alınmıştır.

\section{AMAÇ ve YÖNTEM}

Makalede, tarih boyunca farklı medeniyetlere ev sahipliği yapmış olan Antakya Şehri ve yakın çevresindeki rekreasyon faaliyetlerinin özellikleri ve dağılışı incelenmiş, şehrin yeni rekreasyon alanları için sahip olduğu potansiyel ortaya çıkarılarak, bu potansiyelin değerlendirilmesine yönelik önerilerde bulunulmuştur. Antakya tarihi miras1, kültürel birikimi, doğal güzellikleri ve zengin mutfağı ile rekreasyon faaliyetlerinin geliştirilmesi için çok çeşitli kaynaklara sahiptir. Çalışmanın temel veri kaynaklarını kamu kuruluşlarının hazırladığı rapor ve istatistikler yanında, basılı ve görsel kaynaklar oluşturmaktadır. Şehirde coğrafyanın çalışma alanını oluşturan mekânsal ilișkiler çerçevesinde arazi çalıșmaları da yapılmıştır. Ayrıca şehirdeki rekreasyon faaliyetlerinin dağılışını gösteren haritanın hazırlanmasında AutoCAD ve CorelDRAW programları kullanılmıştır.

\section{BULGULAR}

\subsection{Antakya Şehrinin Genel Özellikleri}

Türkiye'nin güneyinde tarihi İpek Yolu güzergahında yer alan Antakya şehri tarihi mirası, kültürel birikimi, doğal güzellikleri ve zengin mutfağı ile rekreasyon faaliyetlerinin geliştirilmesi için çok çeşitli kaynaklara sahiptir.

Amanos Dağları (Nur Dağları) ile Habib-i Neccar Dağı 
(Silpius) arasındaki vadide kurulan ve içinden Asi Nehrinin geçtiği Antakya, orta Paleolitik Çağ' dan beri yerleşilen bir bölge olma özelliğine sahiptir. Tarihsel süreç içinde pek çok medeniyete (Akad, Babil, Hitit, Hurri, Mittanni, Misır sonra tekrar Hitit, Pers, Makedon, Roma, Bizans, Selçuklu, Memluk ve Osmanlı) ev sahipliği yapan Antakya'nın kuruluşu, M.Ö. 305-300 Roma dönemine rastlasa da, şehri kuran ve ismini veren Komutan I. Selevkos’tur (Demir, 1996; Dinç, 2015; İstek, 2020).
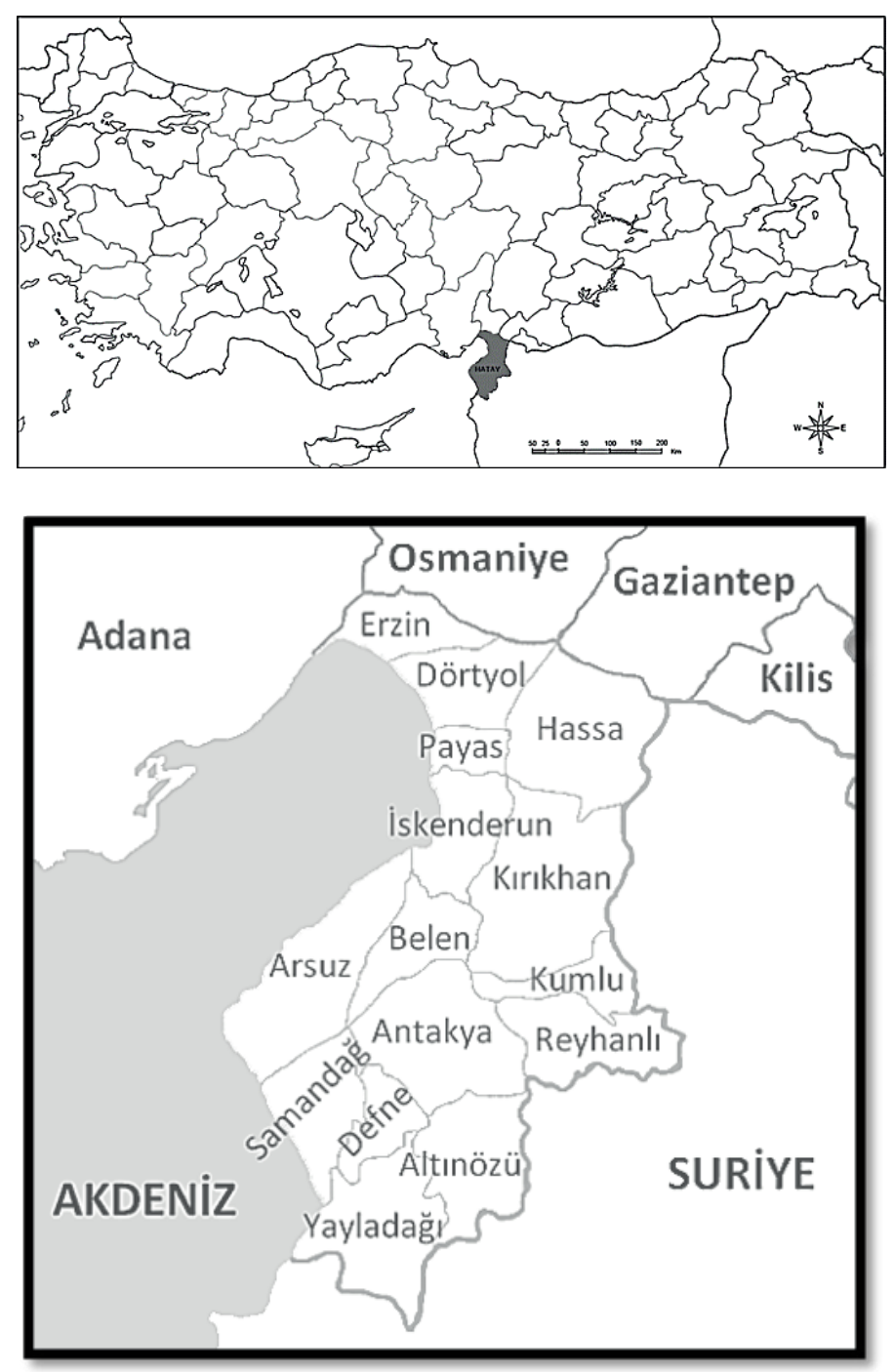

Şekil 1: Antakya'nın Konumu. Figure 1: Location of Antakya.

Makedon Kralı Büyük İskender'in ölümünden sonra imparatorluk toprakları dört komutanı arasında paylaşılmış ve Antakya şehrinin üzerinde kurulduğu topraklar Komutan I. Selevkos Nikator'a düşmüştü. Komutan bu topraklar üzerinde oğlu I. Antiokhos Soter'in adına ithafen Antiokheia (Antakya) şehrini kurmuştur. Şehir, zamanla büyüyerek Selevkosların merkezi olmuştur. M.Ö. 64'te Roma topraklarına katılan şehir, Roma dönemi boyunca gelişimini sürdürmüş, imparatorluğun doğusunda önemli bir askeri, ticari ve kültürel merkezi olarak en parlak dönemini yaşamıştır (Türkiye İller Ansiklopedisi, 2005; İstek, 2020).

Birçok medeniyetin egemenliğinde kalan Antakya, farklı inançlara ev sahipliği yaparak gelişimini sürdürmüştür. Hristiyanlık burada şekillenmiş ve buradan Roma'ya yayılımıștır (Bahadır, 2013; İstek, 2020). Hz. İsa'nın havarilerinden Aziz Petrus'un, Hristiyanlık dinini Antakya'da yaymaya çalışması, ilk kilisenin Antakya'da kurulması ve ilk vaftiz törenin burada yapılması, şehrin Hristiyanlık dünyası için önemli bir merkez olmasını sağlamıştır. Hz. İsa'nın ölümünden sonraki 3. yüzyılda eski önemini yitirmeye başlayan şehir, Bizanslılar ve Araplar arasında sık sık el değiştirmiştir. Sonraki dönemlerde bölgeye sırasıyla Selçuklu, Memlük ve Osmanlılar hâkim olmuşlardır. I. Dünya Savaşı'ndan sonra ise bir süre Fransız işgalinde kalan şehir Suriye'ye bağlanmıştır. (Türkiye İller Ansiklopedisi, 2005; Dinç, 2015). Daha sonra bölgede 2 Eylül 1938'de Hatay Cumhuriyeti kurulmuştur. Hatay Cumhuriyeti Parlamentosu'nun 23 Haziran 1939'da aldığ kararla şehir Türkiye sınırlarına dâhil olmuştur (Dayı, 2002; Dinç, 2015).

Antakya'nın zengin kültürel yapısının oluşmasında tarihi özellikleri yanında sahip olduğu coğrafi şartların da etkisi olmuştur. Akdeniz ikliminin görüldüğü bölge, verimli toprakları sayesinde aynı zamanda zengin bir tarım bölgesi olma özelliğine sahiptir. Verimli tarım topraklarında yetişen çok çeşitli ürünler şehrin mutfak kültürünün gelişmesini sağlamıştır. Ayrıca şehrin geçmişte önemli ticaret yollarından biri olan İpek Yolu güzergâhında bulunması șehrin kültürel yaşantısının da zenginleşmesine katkı sağlamıştır (Dinç ve Karagel, 2017). Günümüzde de Antakya Şehri, sahip olduğu güçlü ulaşım alt yapısıyla (Antakya-Reyhanlı karayolu ile Suriye'nin Halep Sehri'ne; Antakya-Yayladağı karayolu ile Suriye'nin liman kenti Laskiye'ye ve E-391 karayolu ile Güneydoğu Anadolu'ya ulaşılmaktadır. Ayrıca Avrupa- Anadolu- Ortadoğu ve Güney Asya'yı birbirine bağlayan E-91 karayolu da Antakya sınırları içinden geçmektedir) ticari faaliyetlerin yoğun olduğu bir bölgedir (Başeymez, 2009; Çetin, 2012; Dinç, 2015). Güçlü ulaşım alt yapısı, şehrin ekonomik özelliklerinin yanı sıra kültürel yapısının gelişmesine de katkı sağlamaktadır.

Antakya tarih boyunca önemli ticaret yolları üzerindeki konumu sayesinde her zaman nüfusu kendisine çeken bir şehir olmuştur. Ticaret yanında diğer şehirsel fonksiyonlardaki (tarım, turizm, ulaşım vb.) gelişmeler şehrin nüfusunun artmasını sağlamıştır. Artan nüfusun rekreasyonel ihtiyaçlarını karşılamak için şehir genelinde çeşitli donanımlar oluşturulmuştur. 


\subsection{Antakya'da Rekreasyon Faaliyetlerinin Özellikleri} ve Dağılışı

Antakya sahip olduğu doğal, tarihi ve kültürel özellikleriyle rekreasyon faaliyetlerinin geliştirilmesi için çok çeşitli kaynaklara sahiptir. Antakya'daki rekreasyon faaliyetlerini şehirsel ve kırsal alanlarda gerçekleştirilenler şeklinde iki grupta ele almak uygun olacaktır.

\subsection{1. Şehirsel Rekreasyon Faaliyetleri}

Şehirsel rekreasyon faaliyetleri kapalı ve açık mekânlarda gerçekleştirilmelerine göre iki gruba ayrılarak incelenecektir.

\subsubsection{Kapalı Mekânlarda Gerçekleştirilen Rekreasyon} Faaliyetleri

Antakya'da şehirsel rekreasyon faaliyetleri için kullanılan kapalı mekanları sahip oldukları özelliklere göre; eski mahalleler ve caddeler, dini yapılar (camiler, kiliseler, havralar), çarşılar, hamamlar, yeme içme olanağı sunan mekanlar, müzeler, sinema ve tiyatrolar, spor tesisleri, alışveriş merkezleri ve kongre-fuarfestival alanları şeklinde gruplandırmak mümkündür.

Antakya'da tarihi değere sahip mekânlar arasında eski mahalleler ve caddeler, dini yapılar (camiler, kiliseler, havralar), çarşılar ve hamamlar bulunmaktadır. Bunlardan eski mahalleler (Zenginler Mahallesi, Yeni Cami Mahallesi) Antakya'nın doğusunda yer almaktadırlar., Bu mahalleler geleneksel mimari örneği Antakya evleri ve dar sokaklarıyla Antakya'nın en çok ilgi gören rekreasyonel alanlarını oluşturmaktadırlar. Mahallelerdeki eski Antakya evleri, bölgenin geleneksel mimarisi ve yaşayış tarzını yansıtmaları açısından son derece önemlidirler. Dar sokaklarla birbirlerinden ayrılan evler, aile mahremiyetini sağlayan yüksek duvarlarla çevrilidirler (Cengiz, 2014). Genellikle tek ya da iki katlı olarak inşa edilen, avlulara sahip bu evlerin hemen hepsinin avlusunda Akdeniz iklimine özgü portakal ve limon ağaçlarının yanı sıra, süs havuzları evlerden bağımsız olarak inşa edilen mutfak, banyo ve tuvaletleri bulunmaktadır (Çelebi, 1982). Evlerin bazıları sıvaları dökülmüş kapıları kırık ve bakımsız durumda iken, bazıları ise restore edilerek butik otel (Çiçekli Konak, Jasmin Konak Butik Otel, Kavinn Butik Otel vb.) lüks restaurant-meyhane (Konak Restaurant, Müzeyyen Restaurant, Avlu Restaurant, Leban Restaurant vb.), kahvaltı evi (Antakya Kahvaltı Evi, Hatay Sultan Sofrası), cafe, hediyelik eşya dükkânı ve müze (Hatay Tıbbi ve Aromatik Bitkiler Müzesi) olarak kullanılmaktadırlar (Sargın ve Dinç, 2017).

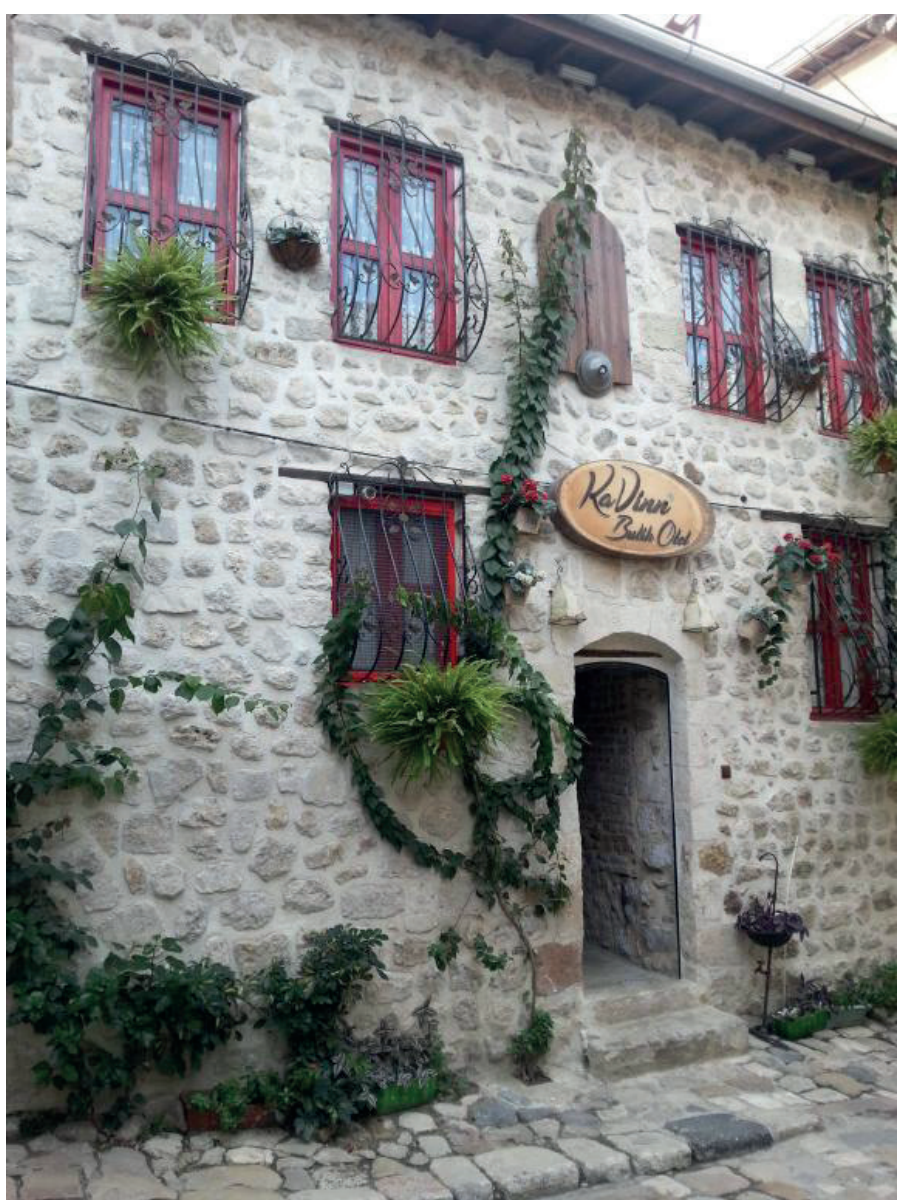

Şekil 2: Kavvin Butik Otel.

Figure 2: Kavvin Boutique Hotel.

Şehrin eski mahallelerinden "Zenginler Mahallesi" adını geçmişte bu mahallede yaşayan varlıklı Yahudilerden almaktadır. Mahallenin sahip olduğu tarihi değerler arasında, geleneksel evler yanında Antakya Musevi Havrası, Sarımiye Cami, Antakya Türk Katolik Kilisesi ve tarihi Cindi Hamamı gibi yapılar da bulunmaktadır. Günümüzde sit alanı olarak ilan edilen mahallede, geleneksel mimari özelliklere sahip evler, restore edilerek, otel, cafe, restaurant, meyhane olarak kullanılmaktadırlar(Bahadır, 2013; İstek, 2020). Mahallenin dar sokaklarında faaliyet gösteren küçük dükkânlarda ise biblolar, ipekli kumaştan yapılan yerel giysiler, mozaik panolar gibi hediyelik eşyalar satılmaktadır.

Antakya'nın rekreasyonel açıdan ilgi gören tarihi mahallelerinden birisi de "Yeni Cami Mahallesi"dir. Burası şehrin en eski alış-veriş mekanı olan Uzun Çarşı'yı da içine almaktadır. Uzun Çarşı günümüzde de şehrin en önemli alışveriş mekanı olma özelliğini korumaktadır. Çarşı yerel halk yanında şehre gelen ziyaretçilere sunduğu uygun fiyatlı yemeiçme olanaklarıyla, şehirde en çok ziyaret edilen yerlerin başında gelmektedir. Çarşı içinde şehrin en çok ilgi gören yiyeceklerini 
sunan tarihi işletmeler bulunmaktadır. Bunlar arasında kebapçılar (Pöç Kasabı), künefeciler (Çınaraltı Künefe Salonu) ve esnaf lokantaları ilk sıralarda yer almaktadırlar.

Antakya'da şehirsel rekreasyon faaliyetlerinin en fazla yoğunlaştığı alanlardan birini de tarihi kent merkezinde yer alan "Kurtuluş Caddesi" oluşturmaktadır. Cadde üzerinde Antakya'nın kültürel zenginliğinin en önemli göstergeleri arasında yer alan üç dine ait yapılar (Sarımiye ve Habib-i Neccar camileri, Antakya Musevi Havrası ve Antakya Türk Katolik Kilisesi) bir arada bulunmaktadırlar. Ayrıca cadde üzerinde şehir halkı ve şehre dışardan gelenlerin sıklıkla ziyaret ettikleri İnci (Affan) Kıraathanesi ve Hatay Tıbbi ve Aromatik Bitkiler Müzesi gibi mekanlar da bulunmaktadır. Cadde üzerinde yer alan çok sayıdaki tarihi evlerin bazıları restore edilerek rekreasyon amaçlı kullanılırken, bazıları ise yakın zamana kadar bakımsız bir şekilde kaderine terk edilmişti. AncakAntakya Belediyesi'nin himayesinde yürütülen "Kurtuluş Caddesi Tarihi Yapılarının Yeniden Canlandırılması Projesi” ile bölge, şehrin önemli rekreasyon alanlarından biri haline getirilmeye çalışılmaktadır. Halen devam eden proje ile ilgili belediye yetkilileriyle yapılan görüşmelerden, projenin üç aşamada gerçekleştirileceği öğrenilmiştir. Buna göre ilk aşamada, Kurtuluş Caddesinin yayalaştırılması için çalışmalar sürdürülmüş ve caddedeki trafik akışının, Mustafa Kemal Şeyhoğlu Caddesine yönlendirilmesi karara bağlamıştır. Projenin ikinci etabında Kurtuluş Caddesi üzerindeki binaların ön cephelerinin restorasyonu tamamlanmıştır. Projenin üçüncü etabını oluşturan ışıklandırılma ve yayalaştırılma çalışmaları ise hala devam etmektedir (Antakya Belediyesi, 2021). Proje bittiğinde Kurtuluş Caddesi, eskiden olduğu gibi Antakya'nın rekreasyonel açıdan en önemli merkezi olmayı sürdürecektir.

Şehrin tarihi değerleri arasında dini yapılar da önemli bir yer tutmaktadır. Özellikle çeşitli dinlere ait mekânlar rekreasyonel amaçla sıklıkla ziyaret edilmektedir. Habib-i Neccar Cami, Ulu Cami, Sarımiye Cami, St. Pierre Kilisesi, Antakya Musevi Havrası, Antakya Türk Katolik Kilisesi, Aziz Paul Ortodoks Kilisesi, Antakya Protestan Kilisesi şehrin rekreasyonel açıdan en çok ziyaret edilen dini mekânlarını oluşturmaktadırlar.

Bunlardan "Habibi Neccar Cami" şehrin en çok ziyaret edilen dini yapılarının başında gelmektedir. Antakya'nın M.S. 636 yılında fethedilmesiyle inşa edilen cami, Anadolu'da yapılan ilk cami olma özelliğine sahiptir. M.S. 969'dan sonra, Bizans döneminde kilise, Selçuklular döneminde cami, Haçlilar döneminde kilise, Memluk döneminden (1268 yılı) günümüze kadar da cami olarak kullanılmıştır. Habib-i Neccar adı tek Tanrıya ve Hz. İsa'nın havarilerine ilk inanan ve bu uğurda şehit düşen kişinin adından gelmektedir (Erdem, 2010: 25). Kurtuluş Caddesi'nde yer alan Habib-i Neccar Cami, hem İslam hem de Hristiyan dünyası için önemlidir. Camiye olan ziyaretler bahar ve yaz aylarında turizm sezonuyla birlikte daha da artmaktadır (Dinç, 2015; Hatay İl Müftülüğ̈̈, 2017;Antakya Belediyesi,2020).

Şehri gezmek için gelenlerin sıklıkla ziyaret ettikleri tarihi camiler arasında "Ulu Cami" de yer almaktadır. Asi Nehri kenarında yer alan caminin inşa tarihi bilinmemektedir. Memlûk dönemi eseri olduğu ifade edilmekle birlikte, Osmanlı mimari tarzından izler taşımaktadır. Cami, mimari yapısı, duvarlarındaki altın harflerle yazılı ayetleri ve içindeki değerli halıları ile dikkat çekmektedir (İstek, 2020; Antakya Kaymakamlığı, 2020).

Antakya'da rekreasyonel faaliyetler açısından önemli dini yapılar arasında kiliseler de yer almaktadır. Bunların en çok ilgi göreni dünyanın ilk mağara kilisesi olarak kabul edilen "St. Pierre Kilisesi"dir. Günümüzde müze olarak değerlendirilen kilise, 1963 'te Vatikan tarafından haç yeri olarak ilan edilmiştir. Hristiyan cemaat tarafindan her y1l 29 Haziran'da kilisede düzenlenen ayine dünyanın birçok yerinden Katolik Hristiyanlar katılmaktadırlar (Dinç, 2015;Hatay Valiliği, 2021). Antakya'da sıklıkla ziyaret edilen bir diğer kilise "Antakya Katolik Kilisesi”dir. 19. yüzyılda eski bir Antakya evinin kiliseye dönüştürülmesi ile ibadete açılan yapı, her gün belli saatlerde ziyaretçilere açılmaktadır. Şehirdeki rekreasyonel açıdan önemli bir başka kilise, Kudüs'teki kiliseden sonra en eski Ortodoks kilisesi olan ve Antakya Patrikliği tarafından "Ana Kilise" olarak hizmet veren "Aziz Paul Ortodoks Kilisesi" dir. Bular dışında şehirde ziyaret edilen kiliselerden biri de Fransız döneminde elçilik binası olarak kullanılan binada hizmet veren "Antakya Protestan Kilisesi” dir. (Hatay Valiliği İl Kültür ve Turizm Müdürlüğü:2017a; Antakya Ortodoks Kilisesi 2020).

Antakya'nın rekreasyon faaliyetleri için değerlendirilen tarihi mekanları arasında çarşılar da bulunmaktadır. Şehrin en eski çarşısı olan Uzun Çarşı1, hem Antakya halkının hem de şehre gelenlerin rekreasyonel anlamda en çok ziyaret ettikleri yerler arasındadır. Mimari açıdan yan yana sıralanan çok sayıda dükkan nedeniyle uzun çarşı olarak adlandırılan çarşıda baharatçılar, konfeksiyoncular, kasaplar, kebapçılar, tatlıcılar, kuyumcular, kumaşçılar ve ayakkabıcılar gibi çok çeşitli alanda hizmet veren dükkânlar bulunmaktadır. Antakya'ya özgü pek çok ürünü (baharat, nar ekşisi, kırma zeytin, tuzlu yoğurt, salça, zahter, defne sabunu, peynir, reçel gibi) satın alma olanağı sunması nedeniyle ziyaretçiler tarafından en çok tercih edilen mekanlar arasındadır. Çarşı içinde yeme-içme (kâğıt kebabı ve künefe) olanaklarının bulunması çarşının rekreasyonel çekiciliğini arttırmaktadır. 
Antakya'da tarihi hamamlar da rekreasyonel faaliyetler için değerlendirilmektedirler. Memluk, Selçuklu ve Osmanlı dönemlerinden kalma çok sayıdaki tarihi hamam (Saka Hamamı, Cindi Hamamı, Meydan Hamamı, Yeni Hamam ve Kurtuluş Hamamı gibi), günümüzde de hem Antakyalılar hem de şehre gelen ziyaretçiler tarafından kullanılmaktadır (İstek, 2020). Antakyalılar her biri farklı mahallelerde bulunan hamamlardan genelde kış mevsiminde, evlerine yakın mesafede olanları tercih etmektedirler. Yerel halk günümüzde hamamlardan daha çok düğün (gelin ve damat hamamları) ve sünnet davetleri için yararlanmaktadırlar. Dügün eğlencelerinde gelin hamamı gündüz, damat hamamı ise gece yapılmaktadır. Gelin hamamı geleneksel olarak akrabalar, arkadaşlar ve komşuların davet edilmesiyle hamamda düzenlenen müzik ve ikramlar eşliğinde gerçekleştirilirken, damat hamamı ise, sadece damadın arkadaşlarının müzik ve ikramlar eşliğinde eğlenmesi için düzenlenir. Düğün ve sünnet eğlencelerinin olduğu gün hamam yalnızca düğün sahiplerine hizmet vermektedir. Saka Hamamı şehirdeki diğer hamamlardan farklı olarak içinde bulunan türbe nedeniyle de ziyaret edilmektedir.

Antakya, sahip olduğu yeme-içme olanakları sunan mekanlarıyla rekreasyonel anlamda son derece çekici şehirlerden biridir. Antakya'nın tarih boyunca farklı medeniyetlere ev sahipliği yapmış olması, geçmişte İpek Yolu güzergahında bulunması mutfak kültürünün gelişmesinde son derece etkili olmuştur. Ayrıca bölgede Akdeniz ikliminin egemen olması sayesinde çok çeşitli sebze ve meyvenin varlığı geleneksel mutfak kültürünün zenginleşmesine katkı sağlamıştır.

Geçmişte bölgeye hâkim medeniyetlerin izlerini taşıyan 600 çeşit yemeği ile Antakya mutfağ 1 rekreasyonel açıdan başlı başına bir çekicilik oluşturmaktadır (Hatay Valiliği İl Kültür Müdürlüğü-Hatay Mutfağ1, 2018). Geleneksel Antakya mutfağının en çok bilinen yemekleri; kâğıt kebabı, tepsi kebabl, cevizli biber (muhammara), humus, oruk, (abagannuş), kaytaz böreği, yoğurtlu ekmektir. Geleneksel Antakya yemeklerinde baharat kullanımının yaygın olmasının Romalılar döneminden kalma bir alışkanlık olduğu belirtilmektedir. Aynı şekilde kebap/ ızgara yemeklerinin çokluğu Osmanlı mutfağının etkisinin bir sonucudur (Türk ve Şahin, 2004). Antakya mutfağında yemeklerin lezzetini arttırmada, bazı mevsimsel ürünlerin çeşitli işlemlerden (kurutularak, salamura, turşu ve reçel vb.) geçirilerek yıl boyunca kullanımının sağlanması yanında, yemeklerin bol miktarda taze yeşil sebzelerle (nane, maydanoz, roka, reyhan, soğan, sarımsak vb.) sunulması son derece önemlidir.

Antakya mutfağ 1 yemeklerin yanı sıra, çok çeşitli yöresel yiyecekleri içeren, zengin kahvaltı kültürüyle dikkat çekmektedir.
Kahvaltıda tüketilen yöresel yiyeceklerden bazılarını; humus, bakla, yaz aylarında tuzlu yoğurt, kış aylarında biberli çökelek, zahter salatası, yumurtalı yoğurt, zeytin salatası, ceviz reçeli, zeytin türleri, kızarmış Antakya peyniri ve biberli ekmek gibi sıralamak mümkündür.

Yemek ve kahvaltı dışında Antakya mutfağında tatlı kültürü de son derece gelişmiştir. Antakya mutfağının en ünlü tatlısını künefe oluşturmaktadır. Künefe yerel halkın en çok tükettiği tatlı olduğu için şehir genelinde hemen her mahallede bir yada iki künefeci bulunmaktadır. Şehri ziyaret edenlerin künefe yemek için en çok tercih ettikleri yer ise Uzun Çarşı'dır (Nesipoğlu, 2019).

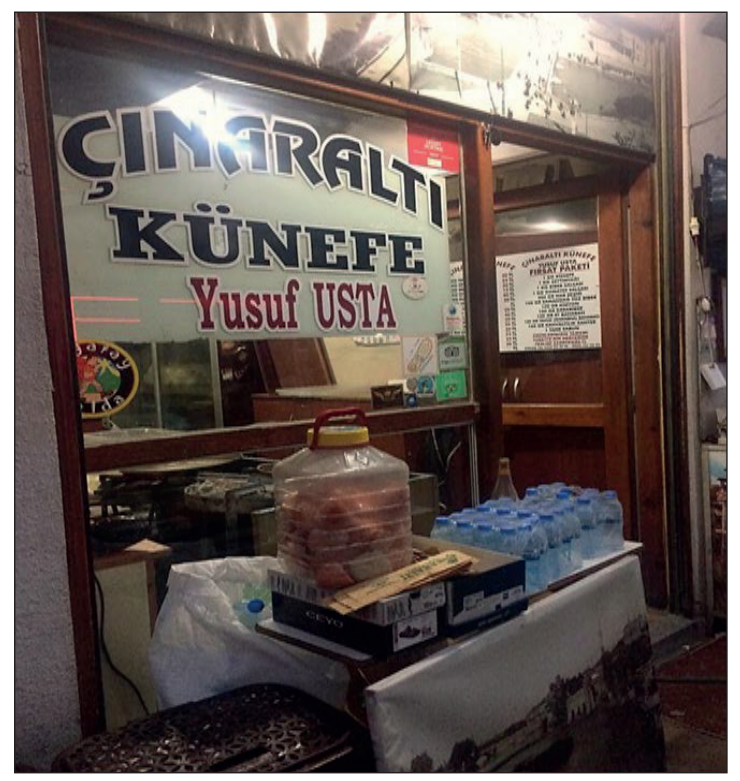

Şekil 3: Antakya'da künefe üretim mekanlardan biri: Çınaraltı Künefe (Yeni Cami Mahallesi).

Figure 3: One of the places producing künefe in Antakya: Çınaraltı Künefe.

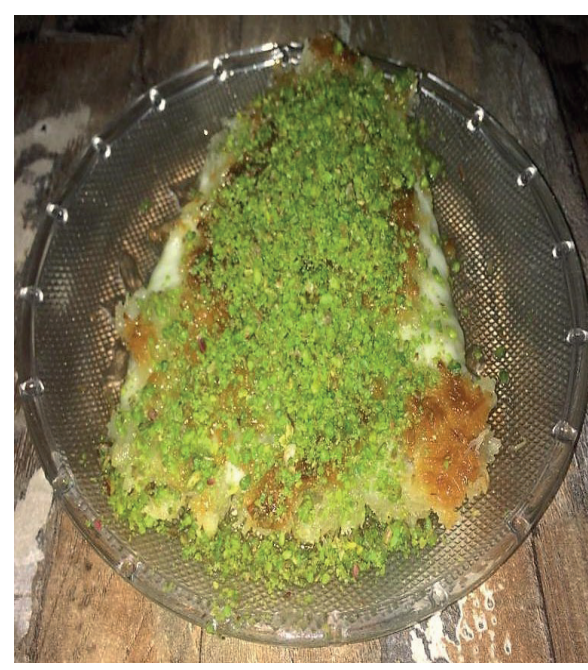

Şekil 4: Künefe.

Figure 4: Künefe. 
Antakyalıların geleneksel içeceğini ise affan kahvesi (şekersiz olarak çay bardağı ile servis edilen) oluşturmaktadır. Şehrin affan kahvesiyle ünlü mekanı ise İnci Kıraathanesi'dir. Antakyalıların geleneksel atıştırmalıklarını ise odun ateşi fırınlarda pişirilen kömbe (zengin baharat içeriği hazırlanan bir tür kurabiye) ve simit oluşturmaktadır (Nesipoğlu, 2019).

Antakya'nın geleneksel mutfak kültürünün yaşatılmasında, şehirde faaliyet gösteren firıncılar, kasaplar, tatlıcılar ve lokantacıların rolü büyüktür. Özellikle şehir genelinde yayılmış olan kasaplar ve firınlar geleneksel mutfağın yaşamasında çok önemli görev üstlenmiş durumdadırlar. Bunlar kendi hazırladıkları geleneksel yemeklerin satışı yanında, yerel halkın öğle ve akşam yemekleri siparişlerini alarak koordineli bir şekilde çalışmaktadırlar. Örneğin Antakya'nın en ünlü yemeklerinden olan "kâğıt kebabı" yada "tepsi kebabı" siparişi alan kasaplar, sipariş için hazırladıkları kebabı kendilerine en yakın firına gönderirler. Fırın kasapların hazırladığı kebapları geleneksel olarak odun ateşinde pişirir ve istenilen saate hazır hale getirir, siparişi veren kişi kebabı firından alır. Kasap ve firıncılar arasındaki bu işbirliği kebaplar dışında Antakya mutfağının diğer geleneksel yiyeceklerinin (lahmacun, biberli ekmek, pide vb) hazırlanmasında da sürdürülmektedir. $\mathrm{Bu}$ işbirliğinin varlığı geleneksel Antakya mutfağının günümüzde de yaşamasını sağlamaktadır (Nesipoğlu, 2019).

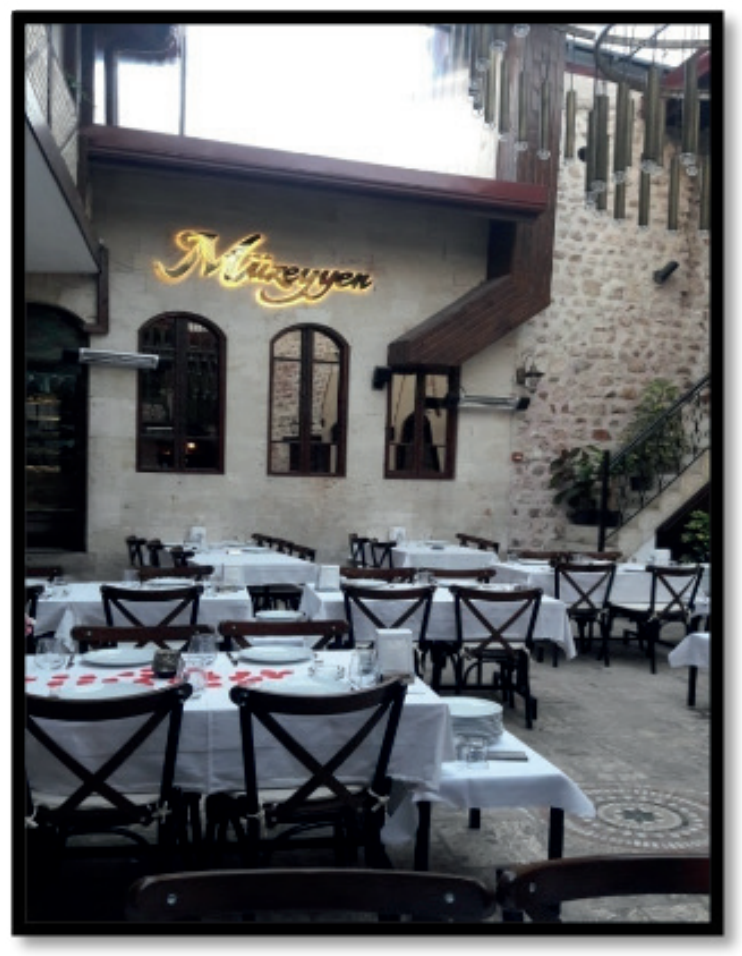

Şekil 5: Müzeyyen Restoran.

Figure 5: Müzeyyen Restaurant.

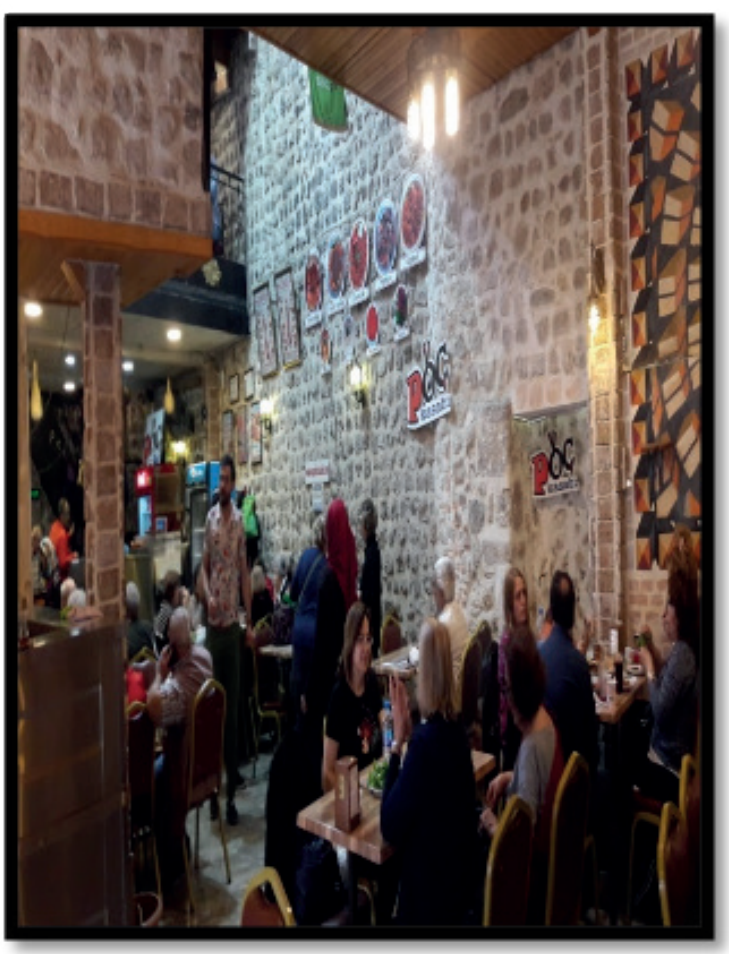

Şekil 6: PÖÇ Kebapçısı (Esnaf Lokantası).

Figure 6: PÖÇ Kebab Restaurant.

Antakya'da yeme-içme olanăg sunan (lokanta, restoran, döner, köfte, kebap ve ciğer) 166 işletme bulunmaktadır. Bunların bir kısmını alkollü içecek de sunan meyhaneler oluşturmaktadır. Bunlar dışında şehirde pastane, cafe, kafeterya, kahvehane, kıraathane, çay ocağı ve fast food gibi yeme içme olanağ sunan 78 işletme daha faaliyet göstermektedir (Antakya Ticaret ve Sanayi Odası:2018).

$\mathrm{Bu}$ işletmelerden geleneksel mutfağa özgü yemekler sunanlar daha çok şehrin tarihi merkezi olan Eski Antakya'da ve özellikle de Zenginler Mahallesi'nde yer alırken, fast food restoranlar (az sayıda şehir geneline yayılsalar da) daha çok alışveriş merkezlerinin içinde yada yakın çevresinde yer almaktadırlar. Antakyalılar fast-food restoranlara daha çok kış dönemi ve hafta sonu tatillerinde yoğun ilgi göstermektedirler. Diğer yeme içme olanağı sunan mekanlar ise şehir geneline dağılmış durumdadırlar (Nesipoğlu, 2019) (Şekil 8).

Geçmişte bölgeye hakim medeniyetlerin izlerini taşıyan 600 çeşit yemeği ile Antakya mutfağı rekreasyonel açıdan başlı başına bir çekicilik oluşturmaktadır. Bu mirasın korunması ve gelecek nesillere taşınması için Hatay Büyükşehir Belediyesi, Hatay Aşçlar ve Turizm Birliği Derneği gibi kuruluşların çalışmaları sonuç vermiş, Antakya 2017'de Birleşmiş Milletler Eğitim, Bilim ve Kültür Kurumu (UNESCO) tarafından 
"Dünyanın 26. Gastronomi Şehri” olarak kabul edilmiştir. Bu unvanı almasından sonra Antakya'da gastronomi turizmi anlamında hızlı gelişmeler yaşanmaya başlamıştır. Antakya'ya düzenlenen gurme turlarına hem yurt içinden hem de yurt dışından yoğun ilgi olmuştur. Son zamanlarda gelişen hava ulaşım olanakları ile İstanbul, İzmir, Ankara gibi büyük şehirlerden gastronomi turizmi kapsamında gelen günübirlik ziyaretçilerin sayısında da önemli artış olmuştur (Hatay Valiliği İl Kültür ve Turizm Müdürlüğü, 2018).

Antakya'nın tarihi ve kültürel özelliklerinin sergilendiği müzeler de rekreasyonel açıdan oldukça çekici özelliklere sahiptir. Şehrin en önemli müzesini "Hatay Arkeoloji Müzesi" oluşturmaktadır. Dünyanın ikinci büyük mozaik müzesi olma özelliğine sahip müzede sergilenen eserler Antakya ve yakınındaki Harbiye (Daphne)'den çıkarılmıştır. Princeton Üniversitesi'nin 1930'larda yaptığı kazılardan çıkarılan mozaikler Roma ve Bizans dönemlerine aittir. Müze, yerel halk yanında, şehir dışından ve yurt dışından gelenlerle şehrin en çok ziyaret edilen müzesi olma özelliğine sahiptir. (Dinç, 2015; Hatay Valiliği İl Kültür ve Turizm Müdürlügü̈, 2017b).

Antakya'nın önemli müzelerinden biri de "St. Pierre Anıt Müzesi"dir. Hristiyanlar için hac merkezi olarak kabul edilen kilise günümüzde anıt müze olarak kullanılmaktadır. Kilise, Antakya'yı ziyaret eden yerli ve yabancı turistlerin en çok ziyaret ettikleri yerler arasındadır (İstek, 2020; St. Pierre Anıt Müzesi, 2020).

Antakya'nın rekreasyonel açıdan ilgi çeken müzelerinden biri de "Hatay Tıbbi ve Aromatik Bitkiler Müzesi"dir. Kurtuluş Caddesi'nde, Uzun Çarşı yakınında yer alan müze, 19. yüzyılda inşa edilen iki katlı eski bir Antakya konağının restore edilmesiyle 2012'de faaliyete başlamıştır. Aynı zamanda Türkiye'nin de ilk "tıbbi ve aromatik bitkiler müzesi" olma özelliğini taşımaktadır (Hatay Valiliği, 2020). Müzede, yöreye has bitki türleri ve kurutulmuş formları bulunmaktadır. Müzeye yerel halkın yanında yabancı turistler de ilgi göstermektedirler. Şehir merkezindeki konumu müzeye olan ilginin artmasına neden olmaktadır.

Antakyalıların rekreasyonel ihtiyaçları için şehirde sinema ve tiyatrolar hizmet vermektedirler. Şehirde iki adet sinema salonu ve iki adet tiyatro salonu bulunmaktadır. Sinema salonlarından biri Palladium AVM'de bulunan "Antakya Palladium Cinens Sineması", diğeri ise Primemall AVM'de yer alan "Antakya Prime Prestigemall Sinemsı"dır. Bu sinemalar teknolojik alt yapılarının yeniliği, film izleme kalitesini arttıran konforlu oturma düzenleri ve AVM'ler içindeki konumlarıla ilgi görmektedirler. AVM içindeki sinemalar film öncesi veya sonrasında sundukları alışveriş ve yeme-içme kolaylıklarıyla yerel halk tarafindan tercih edilmektedir.

Antakya'da sinemalar dışında kültür merkezleri içinde hizmet veren iki tane tiyatro bulunmaktadır. Bunlardan biri Meclis Kültür Sanat Merkezi içinde yer alan 435 koltuklu tiyatro salonudur. Eskiden Hatay Devleti tarafindan parlamento binası olarak kullanılan yapı, Antakyalı İş İnsanı Salih Güney'in tarafından 2010 y1lında restore edilerek Meclis Kültür Sanat Merkez'ine dönüştürülmüştür. Çok amaçlı hizmet veren kültür merkezi içerisinde tiyatro gösterimleri, konserler, film festivalleri, kongreler, konferanslar gibi etkinlikler gerçekleştirilmektedir. Özel tiyatrolara da oyunlarını sergileme olanağı sunan merkez, sunduğu etkinliklerle yerel halkın yanı sıra üniversite öğrencileri tarafından da rekreasyonel anlamda en çok tercih edilen mekanlar arasındadır (Meclis Kültür Merkezi, 2021).

Şehirdeki ikinci tiyatro salonu ise 1987 yllında hizmete açılan Hatay Kültür Merkezi içinde hizmet vermektedir. Kültür merkezi içinde 454 koltuklu tiyatro salonunun yanı sıra galeri, sergi salonu, kütüphane, okuyucu salonu ve misafirhane bulunmaktadır. Tiyatro salonunda tiyatro dışında opera, bale, konser, panel, folklor gösteri gibi diğer sanat etkinliklerinin de halkla buluşması sağlanmaktadır. Şehrin en çok tanınan sanat topluluğu olan "Medeniyetler Korosu" ( yerel halktan oluşan koro, üç semavi dine ve altı mezheblere ait müzik eserlerini icra etmektedir) akşamları burada çalışmalarını sürdürmekte ve yıl sonunda konserler vermektedir.

Antakyalılar için kültür merkezleri hem sanatsal hem de eğitim amaçlı rekreasyon alanı olma özelliğine sahiptirler. Şehir merkezindeki konumlarıyla her yaştan, farklı eğitim düzeyi ve meslekten ziyaretçilere sahiptirler. Ziyaretçilerinin önemli bir kısmını gençler (özellikle üniversite öğrencilerinin) oluşturmaktadır. Halkın yoğun ilgisine rağmen, şehir genelinde bu tür mekanların azlığı dikkat çekmektedir. Şehrin sahip olduğu nüfus miktarı dikkate alındığında kültürel yaşamı zenginleştirecek bu tür merkezlerin sayılarının arttırılması oldukça öneml taşımaktadır.

Antakya halkının en çok ilgi gösterdiği rekreasyonel alanlar arasında spor tesisleri de yer almaktadır. Bu amaçla şehirde 4 adet kapalı yüzme havuzu ve 52 adet kapalı spor salonu faaliyet göstermektedir (Hatay Gençlik ve Spor İl Müdürlüğü, 2020). Bu tesislerden en önemlisi Hatay Büyükşehir Belediyesi 
bünyesindeki spor kompleksidir. Hem açık hem de kaplı spor salonları ile hizmet veren komplekste yüzme fitness, plates, bowling, bilardo gibi 21 farklı spor dalında hizmet verilmektedir. Spor kompleksinden her gün ortalama 1.200-1.500 kişi yararlanmaktadır. Antakyalıların en çok ilgi gösterdikleri spor türleri arasında yüzme, fitness, plates, bowling ve bilardo ilk suralarda yer almaktadır (Antakya Toplumcu Halk Gazetesi, 2021). Spor merkezlerine ulaşım genellikle yürüyerek gerçekleştirilirken, yürüme dışında özel araç, dolmuş ve halk otobüsleri de kullanılmaktadır. Spor faaliyetlerine katılım daha çok hafta içi akşam saatleri ve hafta sonu olmaktadır. Akdeniz iklimine sahip Antakya'da, yaz aylarının çok sıcak geçmesi, bu dönemde şehirdeki kapalı spor salonları ve yüzme havuzlarına olan ilgiyi arttırmaktadır. $\mathrm{Bu}$ mekanlar sundukları klimalı ortamlar ve sahip oldukları cafeler, dinleme ve eğlence olanaklarıyla şehir halkının önemli buluşma noktaları haline gelmektedirler.

Son yıllarda dünya şehirlerinin çoğunda rekreasyonel faaliyetler için en çok tercih edilen mekânlar arasında alış-veriş merkezleri de yer almaktadır. Antakya'da iki tane alış-veriş merkezi bulunmaktadır. Bunlardan biri Antakya merkezde (Haraparası Mahallesi'nde bulunan) yer alması nedeniyle Antakyalıların kolaylıkla erişebildikleri "Palladium Alış-Veriş Merkezi" dir. Şehrin ikinci alış-veriş merkezini ise şehir merkezinin biraz uzağında (Akasya Mahallesi'nde) yer alan "Primemall Alış-Veriş Merkezi" oluşturmaktadır. Primemall Alış-Veriş Merkezi'ne ulaşım şehir merkezinden kalkan toplu taşıma araçları ile sağlanmaktadır. Her iki alışveriş merkezinin içinde alış-veriş olanaklarının yanı sıra McDonald's, Burger King gibi yeme içme hizmeti veren çok sayıda fast food restoranı, kafeler, çocuklar için oyun alanları, gençler için bowling salonları, sinema salonu ve sanat galerisi bulunmaktadır.

Alış-veriş merkezleri yaz-kış sundukları klimalı ortamlarla Antakya halkının (özellikle de gençlerin) en çok rağbet ettikleri rekreasyon alanlarını oluşturmaktadırlar. Bu merkezlerin tercih edilme nedenleri arasında; alış-veriş olanakları yanında yerel yemekler dışında fast food yeme içme olanağı sunmaları, sinema-sergi gibi kültürel aktivitelere yer vermeleri, çocuk oyun alanları, bilardo, bowling gibi sosyalleşme ortamları sunmalarıdır (Nesipoğlu, 2019).

Şehirde gerçekleştirilen kongre, fuar ve festivaller de şehrin rekreasyonel yaşantısını zenginleştirmektedir. Şehirde gerçekleştirilen kongre ve konferanslar için iki önemli mekân öne çıkmaktadır. Bunlardan ilki "Erol Bilecik Kongre Merkezi" (Cumhuriyet Mahallesi'nde), ikincisi ise "Meclis Kültür ve
Sanat Merkezi" (Kanatlı Mahallesi) dir (Şekil:7). Bunlardan Meclis Kültür ve Sanat Merkezi olarak kullanılan yapı, geçmişte Hatay Devletinin parlamento binası olarak kullanılmaktaydı. Yakın zamanda gerçekleştirilen restorasyon çalışmasıyla özgün haline dönüştürülen yapı, 23 Temmuz 2021'de gerçekleştirilen açılış töreniyle sadece kültür ve sanat etkinliklerinin gerçekleştirildiği bir kullanıma sahiptir. Bu iki merkez dışında Güngör Ottoman Palace (Akçaova Mahallesi), Mozaik Otel (İstiklal Caddesi) ve Narin Hotel (Cumhuriyet Mahallesi) gibi bazı oteller de kongre ve konferanslar için kullanılmaktadırlar. Antakya'da yılın belli dönemlerinde fuarlar düzenlenmektedir. Şehirdeki tek fuar alanı ise Akasya Mahallesi'nde bulunmaktadır. 2015 yılında yapımına başlanan ve 2016'da faaliyete geçirilen fuar alanında, pek çok ulusal ve uluslararası fuar (yapı malzemeleri, tarım makineleri, mobilya ve kitap gibi) gerçekleştirilmiştir (Elka Fuar, 2021).

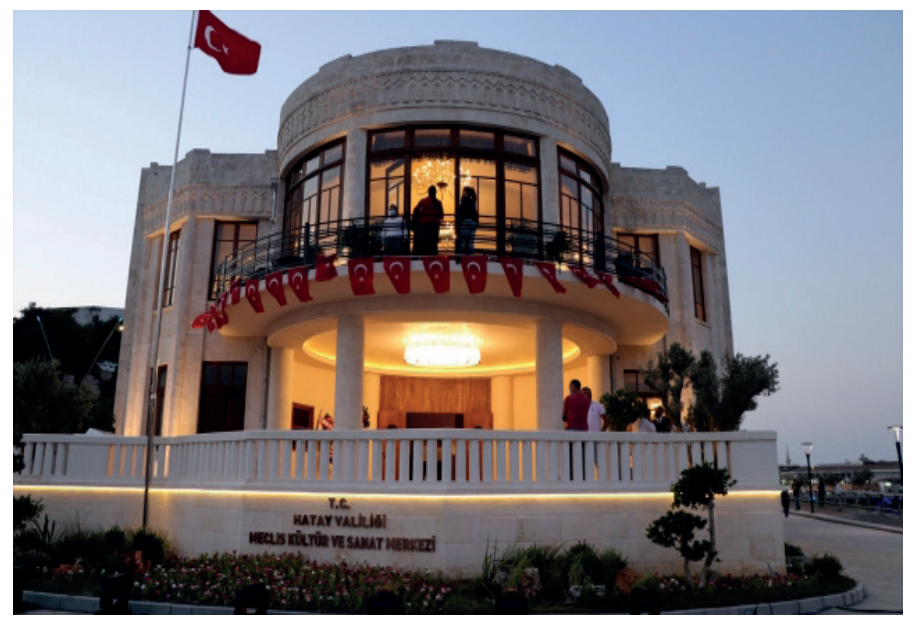

Şekil 7: Meclis Kültür ve Sanat Merkezi (Kanatlı Mahallesi). Figure 7: Meclis Culture and Art Center.

Kaynak: https://www.haberhanesi.com/haber/ Hatayda-Meclis-Kultur-ve-Sanat-Merkezi-ile-Antakya-Konagihizmete-acildi-45593

Şehrin tarihi ve kültürel değerlerini, ulusal ve uluslararası düzeyde tanıtmak amacıyla çeşitli festivaller düzenlenmektedir. $\mathrm{Bu}$ festivallerden bazılarını şu şekilde sıralamak mümkündür: Uluslararası Antakya Kültür Sanat ve Edebiyat Günleri; 19-23 Mart tarihleri arasında düzenlen etkinlik, dünyanın çeşitli ülkelerinin kültürel özellikleriyle tanışma olanağı sunması nedeniyle, yerel halk yanında kültür ve sanat çevrelerince de takip edilmektedir. Özellikle Ortadoğu ve Türk dünyasının önemli yazarlarıyla yapılan söyleşiler ve paneller ilgiyle karşılanmaktadır. Antakya Festivali; Antakya Belediyesi tarafından Hatay'ın anavatana katılışını kutlamak üzere 21-23 Temmuz tarihleri arasında gerçekleştirilmektedir. Üç gün süren 
festivalde, Antakya'nın kültürel özelliklerini tanıtmak hedeflenmektedir. Antakyalıları spordan sanata birçok etkinlikle buluşturan festivale şehir halkı yoğun ilgi göstermektedir. Künefe Festivali; Hatay Büyükşehir Belediyesi tarafından her y1l 23 Temmuz'da düzenlenen festivalde, şehrin geleneksel tatlısı olan künefe çok büyük boyutlarda hazırlanarak $(78 \mathrm{~m})$ festivale katılanlara ikram edilmektedir. Her yaştan şehir halkının yoğun ilgi gösterdiği festival sayesinde şehrin tanıtımı gerçekleştirilmektedir.

Geleneksel Satranç Turnuvası; her yil Türkiye Satranç Federasyonu ve Hatay Büyükşehir Belediyesi iş birliği ile 27 Ağustos'ta düzenlenen ulusal turnuvaya Türkiye'nin her yerinden katılım olmaktadır. Uluslararası Aba Güreşi Şampiyonası; her yıl 16-18 Eylül tarihleri arsında Dünya Aba Güreşi ve Geleneksel Sporlar Federasyonu ve Hatay Büyükşehir Belediyesi iş birliği ile düzenlenmektedir. Kökleri Orta Asya’ya dayanan "aba güreşi” (bir tür yakın savunma sanatı) Eski

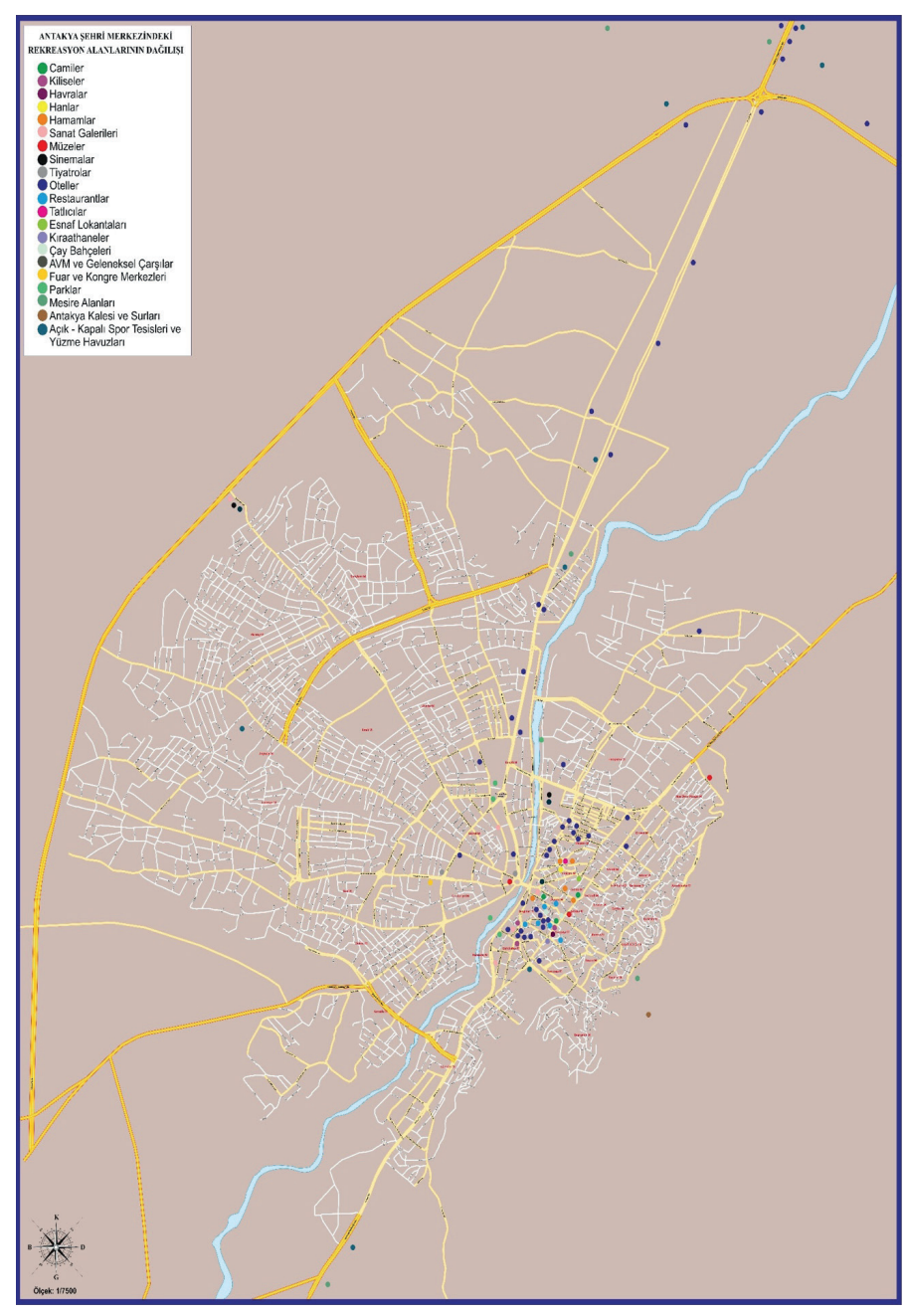

Şekil 8: Antakya'da Rekreasyonel Alanların Dağılışı. Figure 8: Distribution of Recreational Areas in Antakya.
Türklerin barış zamanlarında savaş kabiliyetlerini kaybetmemek için antrenman niteliğinde yaptıkları hareketlerden ortaya çıkmıştır.

Aba güreşinde sporcular, sırtlarına aşırmalı aba giyerek güreşmektedirler. Yerli ve yabancı çok sayıda sporcunun katılımıyla gerçekleşen şampiyonaya şehir halkı yoğun ilgi göstermektedir (Çetin ve Coşkun, 2020).

Uluslararasi Antakya Altın Defne Film Festivali; her y1l aralık ayında Ansam Kültür Derneği tarafından düzenlenen festivalde Berlin ve Cannes gibi film festivallerinde gösterilen filmlerin yanı sıra Türk sinemasından örneklerin şehir halkıyla buluşması sağlanmaktadır. Festivalin yarışma bölümünde en iyi kısa film, en iyi belgesel ve en iyi film dallarında ödüller verilmektedir. Festival süresince şehre gelen yerli ve yabancı sanatçılarla buluşma olanağı sunması nedeniyle Antakyalılar festivale yoğun ilgi göstermektedirler.

\subsubsection{Açık Mekanlarda Gerçekleştirilen Rekreasyon} Faaliyetleri

Şehirlerde kapalı rekreasyon alanları yanında açık havada dinlenme ve eğlenme olanağı sunan mekanlar da mevcuttur. $\mathrm{Bu}$ alanların başında da parklar gelmektedir. Antakya'da parklar rekreasyonel anlamda en çok talep gören yerlerdir. Şehirde halkın rekreasyonel ihtiyaçlarını karşılamak için çeşitli büyüklükte 129 adet park bulunmaktadır (Hatay Belediyesi Park Bahçe ve Yeşil Alanlar Dairesi Başkanlığı, 2018). Şehir halkının en çok ilgi gösterdiği parkları şu şekilde sıralamak mümkündür; Antakya şehir merkezinde yer alan Atatürk Park1 (Cumhuriyet Mahallesi'nde), DSİ 1. Etap Park1 yeni adıyla 15 Temmuz Milli İrade Parkı (Kanatlı Mahallesi’nde), Vali Ürgen Parkı (Kanatlı Mahallesi’nde), Yunus Emre Parkı (Kışlasaray Mahallesi'nde) ve 100. Y1l Park1 (Haraparası Mahallesi’nde) dir.

Tablo 1: Antakya'daki Önemli Parklar. Table 1: XXXXXXXXXXXX.

\begin{tabular}{lll}
\hline Parklar & Bulunduğu Yer ve Büyüklüğü \\
\hline 11 & Atatürk Parkı (Büyük Park) & Cumhuriyet Mahallesi $\left(56.779 \mathrm{~m}^{2}\right)$ \\
22 & $\begin{array}{l}\text { DSi 1. Etap Parkı (15 Temmuz Milli } \\
\text { İrade Parkı) }\end{array}$ & Kanatlı Mahallesi $\left(15.500 \mathrm{~m}^{2}\right)$ \\
33 & Vali Ürgen Parkı (Vali Göbeği Parkı) & Kanatlı Mahallesi $\left(4.993 \mathrm{~m}^{2}\right)$ \\
44 & Yunus Emre Parkı & Kışlasaray Mahallesi $\left(3.500 \mathrm{~m}^{2}\right)$ \\
55 & 100. Yıl Parkı & Haraparası Mahallesi $\left(734 \mathrm{~m}^{2}\right)$ \\
\hline
\end{tabular}

Kaynak: Hatay Belediyesi Park Bahçe ve Yeşil Alanlar Dairesi Başkanlığı, 2021. 
Bunlardan Atatürk Parkı, şehrin en eski park1 olma yanında Antakyalılar tarafından en çok tercih edilenidir (Şekil 9-10). Asi Nehri kenarındaki konumu ve $56.7790 \mathrm{~m}^{2}$ büyüklüğü ile dikkat çekmektedir. Park içerisinde barındırdığı defne, çam, akasya, palmiye, süs eriği gibi çeşitli türlerdeki çok sayıda ağacı ile şehir halkı için dinlenme ortamı sunmaktadır. Ayrıca park içerisindeki çay bahçeleri, büfeler, koşu alanı, çocuk oyun alanları, tarihi çeşme, heykeller, süs havuzları, parkın Asi Nehri'ni gören kısımlarında oluşturulmuş seyir alanları gibi donanımları ile şehir halkının hoşça vakit geçirmesini sağlamaktadır. Park yerel halk tarafindan dinlenmek, yürümek, manzara seyretmek, piknik yapmak, spor yapmak ve sosyalleşmek gibi çeşitli ihtiyaçlar için kullanmaktadır. Yil boyunca yararlanılan park, yaz mevsimi ve hafta sonlarında daha yoğun şekilde kullanılmaktadır (Hatay Belediyesi Park Bahçe ve Yeşil Alanlar Dairesi Başkanlığı, 2018).

Şehrin Atatürk Parkı'ndan sonra rekreasyonel çekiciliği yüksek bir diğer parkı ise "15 Temmuz Milli İrade Parkı"dır. Halk arasında DSI Parkı olarak da bilinen parkın adı, 15 Temmuz girişiminden sonra Antakya Belediye Meclisi kararı ile 15 Temmuz Milli İrade Parkı olarak değiştirilmiştir. Kanatlı Mahallesi'nde yer alan park, $15.500 \mathrm{~m}^{2}$ 'lik bir büyüklüğe sahiptir (Hatay Belediyesi Park Bahçe ve Yeşil Alanlar Dairesi Başkanlığı, 2018). Parkın içerisinde okaliptüs ve çam gibi çeşitli türde ağaçlar, yaya ve bisiklet yolu, çocuk parkı, spor aletleri, banklar, oturma grupları, piknik masaları ve WC bulunmaktadır.

Şehir merkezinde halkın önemli buluşma alanı olarak kullandığı park ise Vali Ürgen Parkı'dır. Parkta içerisinde çeşitli ağaçlar, aslan heykeli ile çevrili bir anıt, su fiskiyeleri bulunmaktadır. Şehir halkı tarafından ilgi gösterilen parklardan biri de Yunus Emre Parkı'dır. Asi Nehri'ne yakın konumu ve sessizliği parkın çekiciliğini arttırmaktadır. Parkta çeşitli türden ağaçlar, oturma bankları, çöp kutuları, çocuk parkı ve küçük bir büfe bulunmaktadır.

Parklar, şehir halkının en çok ziyaret ettikleri rekreasyon alanları arasında yer almaktadırlar. Her yaş grubundan kişilere doğayla baş başa kalma olanağ1 sunan parklara olan ilgi yıl boyunca sürmekte, özellikle yaz aylarında daha da artmaktadır. İlginin fazla olmasına rağmen dünyanın pek çok şehrinde olduğu gibi Antakya'da da kişi başına düşen yeşil alan miktarının yeterli olduğu söylenemez. Ancak Antakya şehirdeki yeşil alan miktarının arttırılması yönünde önemli bir potansiyele sahiptir. Özellikle şehrin yakınında yer alan doğal ormanlık alanların rekreasyonel kullanımının sağlanmasıyla şehirdeki kişi başına düşün yeşil alan miktarı arttırılabilir.

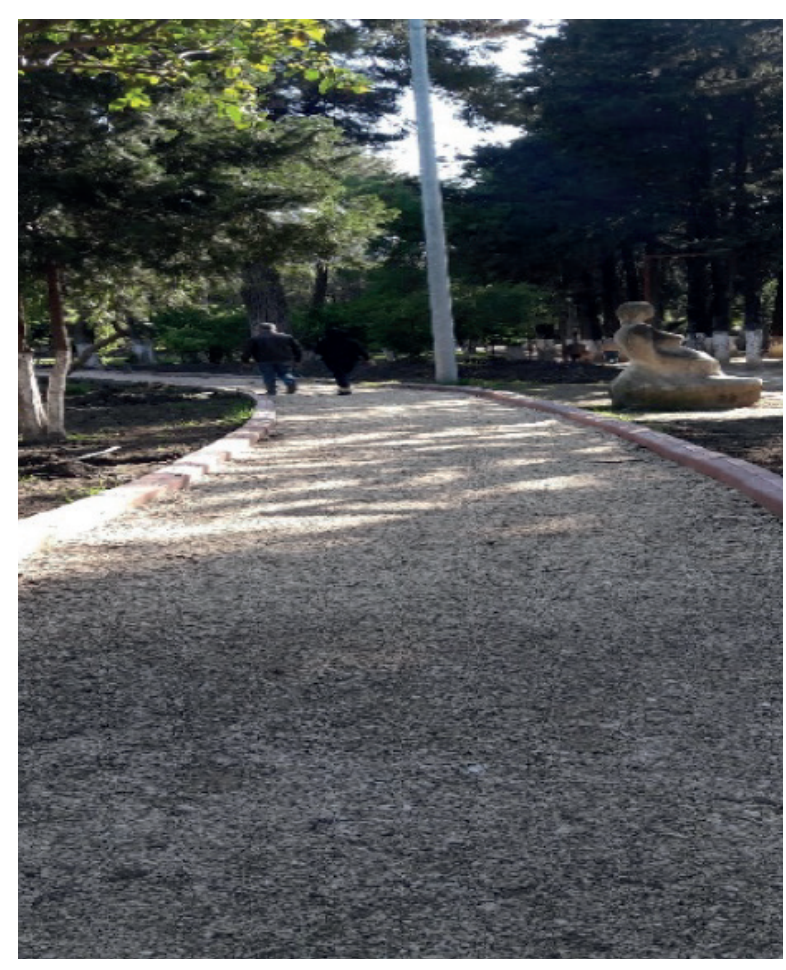

Şekil 9: Atatürk Parkı (yürüyüş yolu). Figure 9: Ataturk Park (walking).

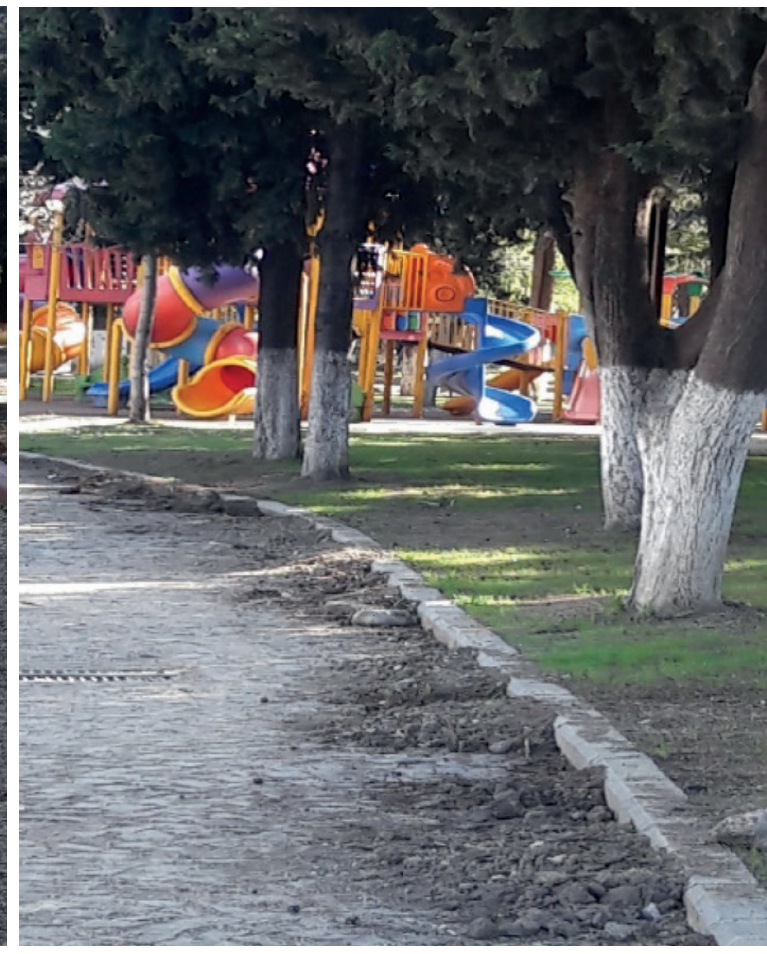

Şekil 10: Atatürk Parkı (çocuk oyun alanı). Figure 10: Ataturk Park (children's play area). 
Antakya'da açık alan rekreasyonel faaliyetlerinin gerçekleştirildiği mekanlar arasında parklar dışında çeşitli spor tesisleri de bulunmaktadır.

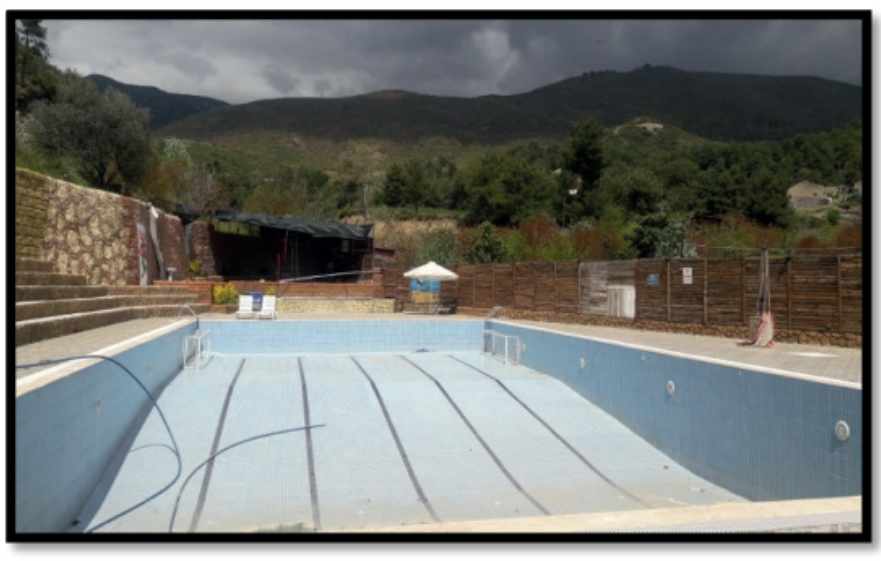

Şekil 11: Tulpar Tesisi.

Figure 11: Tulpar.

Bunlar arasında stadyum, halı sahalar, basketbol sahaları, bisiklet kullanım alanları ve yüzme havuzları vb. bulunmaktadır. Bu mekanlardan “Antakya Atatürk Stadyumu” gerçekleştirilen futbol ve aba güreşi karşılaşmaları nedenleriyle halkın ilgisinin en yoğun olduğu mekandır. Antakya halkının en çok ilgi duyduğu spor dalı futboldur. Özellikle erkeklerin büyük keyif alarak izledikleri futbol müsabakalarına kadınlar da ilgi göstermektedirler. Ancak şehir merkezinde yer alan stadyumun kapasitesinin yetersiz olması nedeniyle, Hatay Gençlik Hizmetleri ve Spor İl Müdürlüğü ve Hatay Belediyesi iş birliği ile şehrin başka bir bölgesinde yeni bir stadyum yapılması için çalışmalar yürütülmektedir. Şehrin açık hava spor olanağı sunan mekanları arasında havuzlar da bulunmaktadır. Havuzlar özellikle yaz aylarında yüzme olanağı sunmaları yanında, sahip oldukları cafeler, dinleme ve eğlenme olanaklarıyla da ilgi çekmektedirler. Antakya Belediyesi, Antakya halkının açık alanlarda daha çok spor yapmasını sağlamak için, parkların içinde yürüyüş ve fitness alanları da oluşturmuştur.

\subsubsection{Kirsal Rekreasyon Faaliyetleri}

Kirsal rekreasyon faaliyetlerinin, şehirsel rekreasyon faaliyetlerinden en önemli farkı geniş arazi kullanımı ve bazı doğal özellikler gerektirmeleridir. Şehir merkezlerinde yeterince büyük ve açık alanların bulunmaması daha geniş alanlara ihtiyaç duyan bu faaliyetlerin şehre yakın alanlarda gerçekleştirilmelerini zorunlu kılmaktadır (Sevil, 2012; Özgüç, 2017). Antakya yakınında da şehir halkının dinlenmesi ve eğlenmesi için oluşturulmuş kırsal rekreasyon alanları bulunmaktadır. Bunlar arasında mesire ve piknik alanları yanında eğlence parkları da bulunmaktadır.

Antakyalıların şehir merkezi dişında rekreasyonel anlamda en çok ziyaret ettikleri yer Harbiye (Daphne) Mesire Alanı'dır (Şekil:12). İçerisinde şelalelerin de bulunduğu Harbiye mesire alanı antikçağda Selevkoslar döneminden beri, doğal, tarihsel ve kültürel çekiciliği nedeniyle dinlenme alanı olarak kullanılmaktadır (Kaymaz ve Özşahin, 2015). Antakya'nın güneyinde şehir merkezine $8 \mathrm{~km}$ uzaklıkta olan Harbiye, bol oksijenli temiz havası, kızılçam ormanları, irili ufaklı şelaleleri ile ilgi çekmektedir. Şelaleler yakınında yer alan çok sayıda cafe, restoran ve piknik alanlarıyla Harbiye, yerel halkın yanı sıra Antakya'yı ziyarete gelen yerli ve yabancı turistlerin de mutlaka ziyaret ettikleri yerler arasındadır. Harbiye'deki restoranlar sundukları geleneksel Antakya yemekleri ile bölgenin çekiciliğini daha da arttırmaktadırlar.

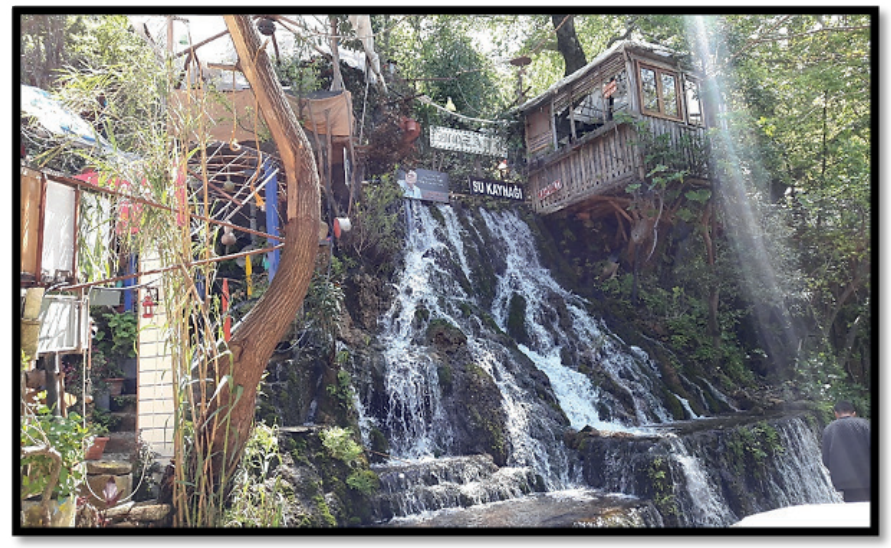

Şekil 12: Harbiye Şelaleleri.

Figure 12: Harbiye Waterfalls.

Bölge içinde yer alan piknik alanları şehir halkı tarafından yoğun şekilde kullanılmaktadır. Belli bir ücret karşılığg girilen bu alanlarda masa, sandalye, mangal, çeşme ve WC gibi donamımlar bulunmaktadır. Antakya halkı tarafindan yıl boyunca tercih edilen Harbiye şelaleleri, serinletici etkisi nedeniyle özellikle yaz aylarında ve hafta sonlarında daha çok ziyaret edilmektedirler. Bölgeye ziyaretlerin yoğun olmasında Antakya merkeze yakın oluşunun yanı sıra, ulaşım kolaylığının etkisi de bulunmaktadır. Uzun Çarşı çıkışından hareket eden minibüsler ya da özel araçlarla Harbiye'ye kolaylıkla ulaşılmaktadır.

Antakya'nın yakınında yer alan dinlenme alanlarından biri de Habib-i Neccar Sosyal Tesisleri dir. Hatay Büyükşehir Belediyesi tarafından Habib-i Neccar Dağı eteklerinde 672.000 
$\mathrm{m}^{2}$ 'lik alan üzerine kurulu tesis, Antakya'yı tepeden izleme ve doğayla iç içe olma olanağı sunmaktadır (Hatay Belediyesi Park Bahçe ve Yeşil Alanlar Dairesi Başkanlığı, 2018). Tesis kent ormanı içinde piknik yapmanın yanı sıra buradaki çeşitli sosyal tesislerden yaralanma olanağı ile hem yerli halk hem de şehri ziyarete gelenler tarafından ilgi görmektedir. Kış mevsiminde soğuk nedeniyle tesise olan ilgi azalırken, ilkbahar ve yaz mevsiminde özellikle de akşamları Antakya'yı tepeden izlemek için tercih edilmektedir.

Antakya'nın yakınında (Tahtaköprü Mahallesi'nde) yer alan bir başka dinlenme alanı ise Tahtaköprü Yıldırım Deresi Mesire Alanı dır. Burası Antakya Belediyesi'nin girişimi ile 2017'den beri mesire alanı olarak kullanılmaktadır. Bölge içinde yer alan Yıldırım Deresi, yarattığı serinlikle, özellikle yaz aylarında mesire alanın çekiciliğini daha da arttırmaktadır. Şehir halkına merkezden fazla uzaklaşmadan dinlenme olanağı sunması nedeniyle özellikle hafta sonları yoğun şekilde kullanılmaktadır. Bölgeye ulaşım genellikle özel araçlarla sağlanmaktadır.

Antakyalıların kırsal rekreasyon faaliyetleri için tercih ettikleri mekanlardan biri de Karlısu Göleti ve Macera Parkı'dır. Hatay Büyükşehir Belediyesi tarafından Karlısu Mahallesi'nde $14.450 \mathrm{~m}^{2}$ alan üzerine inşa edilen park, 2018'den beri hizmet vermektedir (Hatay Belediyesi Park Bahçe ve Yeşil Alanlar Dairesi Başkanlığı, 2018). İçinde, Karlısu Gölet'inde su sporları (yüzme, su kayağı vb) yapma olanağı yanında piknik alanları, seyir terası, yürüyüş parkuru, çocuk oyun grubu, 1000 kişilik düğün salonu, WC ve otopark bulunmaktadır. Antakya halkının doğayla iç içe rekreasyonel faaliyetlerde bulunması ve eğlenmesi için tasarlanan parka, her yaştan Antakyalı ilgi göstermektedir. Bölgeye ulaşım özel araçlarla sağlanabilmektedir.

\section{SONUÇ}

Antakya sahip olduğu kültürel ve doğal özellikleriyle rekreasyon faaliyetlerinin geliştirilmesi için uygun koşullara sahip şehirlerden biridir. Çeşitli medeniyetlere ev sahipliği yapan ve tarih boyunca önemli ticaret yolları üzerinde yer alan Antakya tarihi ve kültürel özellikleriyle son derece zengin bir şehirdir. Bu zenginlik şehirde rekreasyon faaliyetlerinin geliştirilmesine kaynaklık etmektedir. Bu kaynaklar arasında en önemlilerini geçmiş medeniyetlerden günümüze kalan tarihi yapılar oluşturmaktadır. Bu yapıların (Ulu Cami, Habib-i Naccar Cami, Uzun Çarşı, Antakya Musevi Havrası, Katolik Kilisesi, Ortodoks Kilisesi, St. Pierre Kilisesi ve geleneksel mimarileriyle Antakya evleri vb) önemli bir kısmı günümüzde rekreasyonel kullanımlarıyla şehir halkına hizmet vermektedirler.
Ancak şehrin bazı tarihi değerlerinden yararlanılmadı̆̆ 1 görülmüştür. Bunların en önemlisi Antakya Kalesi ve surlarıdır. Kale ve surlar, bölgeye egemen olmuş Selevkoslar, Romalılar, Bizanslılar, Haçlılar, Selçuklular ve Osmanlılar tarafindan kullanılarak günümüze kadar gelmeyi başarmışlardır. Tarihi süreç içinde savaşlar ve depremlerden zarar gören yapıdan günümüze Silpius Dağındaki sur kalıntıları ile Demir Kapı bölümündeki kalıntılar kalmıştır. Ancak bu kalıntılardan günümüzde hiçbir şekilde yararlanılmadığı görülmüştür. Oysa bu kalıntılar, kapsamlı bir turizm planlamasıyla (çevresel ve tarihi koruma, yeme içme olanakları, ulaşım kolaylıkları vb) rekreasyonel açıdan değerlendirilmesi gereken çok önemli kaynaklardır.

Antakya'nın kültürel zenginliğinin göstergelerinden biri de, geçmişte bölgeye hakim olmuş medeniyetlerin izlerini taşıyan 600 çeşit yemeği ile geleneksel Antakya mutfağıdır. Geleneksel Antakya mutfağı 2017 'de Unesco tarafindan tescillenmiş ve Antakya "Dünyanın 26. Gastronomi Şehri" olarak kabul edilmiştir. $\mathrm{Bu}$ unvanla Antakya, hem Türkiye'nin hem de dünyanın önemli gastronomi turizmi merkezlerinden biri olmak için önemli bir şans elde etmiştir. Bu şansı iyi değerlendirebilmesi için şehrin mutfak kültürünün tanıtılması için gerekli alt yapı (yemek festivalleri, yemek turları, yerel pazarlar ve üretici gezileri, aşçılık workshopları vb.) hızla oluşturulmalı ve Antakya'nın bir dünya gastronomi merkezi olması için çaba harcanmalıdır. Bunun için tur operatörleri ve seyahat acentelerinin Antakya'ya yönelik gastronomi turlarını çeşitlendirerek arttırılmaları ve bunları tanıtan kampanyalar düzenlemeleri şehrin tanıtımına katkı sağlaması açısından son derece önemlidir. Antakya mutfağının yaşamasının teminatı olan yöresel yiyecekleri üreten çiftçilerin desteklenmesi de geleneksel mutfağın yaşatılması açısından son derece önemlidir. Şehirde geleneksel mutfağa özgü yemekleri sunan mekanların desteklenerek sayılarının arttırılması da hem dışardan gelenlere hem de yerel halka verilen hizmetin kalitesini arttıracağ 1 için önemlidir. Son zamanlarda gelişen hava ulaşım olanakları ile İstanbul, İzmir, Ankara gibi büyük şehirlerden gastronomi turizmi kapsamında gelen günübirlik ziyaretçilerinin sayısı artmış olsa da yeterli değildir. Antakya'nın dünya çapında bir gastronomi merkezi olabilmesi için ulaşım (özellikle hava yolu) olanakları yeniden gözden geçirilmeli ve gerekli yatırımlar bir an önce gerçekleştirilmelidir.

Antakya, rekreasyon faaliyetlerinin geliştirilmesi için tarihi ve kültürel kaynaklar yanında doğal kaynaklar (doğal ormanlar, Asi Nehri, Harbiye Şelaleleri vb) bakımından da önemli bir potansiyele sahiptir. Şehir içinde ve yakın çevresindeki orman 
alanlarında çok sayıda park ve mesire yeri oluşturularak halkın kullanımına sunulmuştur.

Şehrin en önemli doğal kaynaklarından birini de Asi Nehri oluşturmaktadır. Nehrin bazı kesimlerini içine alan parklarda, manzara terasları oluşturularak nehirden rekreasyonel anlamda yararlanılsa da bu yeterli değildir. Bu kaynağın hem su sporları hem de nehir kenarı rekreasyon üniteleri oluşturularak değerlendirilmesi, şehrin rekreasyonel hayatına canlılık katacaktır.

Şehrin rekreasyonel anlamda değerlendirilen doğal kaynaklarından biri de şehrin yakınında doğal orman örtüsü içerisinde yer alan Harbiye Şelaleleri'dir. Burası şehir halkının rekreasyonel anlamda en çok ziyaret ettikleri yerler arasındadır. Ancak bölgedeki yeme-içme ve diğer hizmetleri veren işletmelerin ( restoranların, cafe, yöreye özgü hediyelik eşya satan dükkânların) gelişigüzel dağılışı bir karmaşa yaratmakta ve şelalelerin görünürlüğünü zedelemektedir. Bu durumun doğal orman örtüsü korunarak oluşturulacak yeni bir çevre düzenlenmesiyle ele alınması önemlidir. Hazırlanacak çevre düzenlemesi planında bölgenin heyelan tehlikesi de göz önünde bulundurulmalıdır.

Antakya rekreasyon faaliyetlerinin gelişimi açısından önemli gelişmeler kaydetmiş olsa da, bu alanda hala bazı eksiklikler mevcuttur. Bu eksiklikler ve giderilmesine yönelik önerileri şu şekilde sıralamak mümkündür:

- Dünyanın ikinci büyük mozaik müzesi olan Hatay Arkeoloji Müzesi'nin etkili bir tanıtım kampanyasıyla tanıtımının yapılması şehrin tanıtımı açısından oldukça önemlidir.

- Parklar, şehir halkının en çok ziyaret ettikleri rekreasyon alanları arasında yer almaktadırlar. Parklara ilginin fazla olmasına rağmen dünyanın pek çok şehrinde olduğu gibi Antakya'da da kişi başına düşen yeşil alan miktarının yeterli olduğu söylenemez. Ancak Antakya yeşil alan miktarının arttırılması için önemli potansiyele sahiptir. Şehrin yakınındaki doğal ormanlık alanların rekreasyonel kullanımının sağlanması ile şehirdeki kişi başına düşün yeşil alan miktarı arttırılabilir.

- Şehir merkezindeki bazı yolların trafiğe kapatılarak, yürüyüş ve bisiklet yolu olarak değerlendirilmesi uygun olacaktır.

- Şehir içi ulaşımla ilgili bazı eksiklikler de tespit edilmiştir. Bunlardan biri şehirdeki otoparkların yetersizliğidir. Otoparkların sayısının arttırılmasına ihtiyaç vardır. Ayrıca toplu taşıma araç sayısının arttırılması ve raylı sistemlerin oluşturulması ile şehir trafiğinin daha da rahatlaması sağlanmalıdır. Şehrin yakınında yer alan bazı rekreasyon alanlarına (Karlısu Göleti gibi) ulaşım sağlayan toplu taşıma araçlarının yetersizliğinden kaynaklanan sorunların giderilmesi için de araç sayısını arttırma yanında düşük ücretli ring servisleri hizmete konulabilir.

- Hatay Kültür ve Turizm İl Müdürlüğü tarafindan şehrin çeşitli noktalarına; parklara, otobüs duraklarına ve hava alanına turistik haritalar yerleştirilebilir.

- Yüksek kapasiteli kongre merkezleri oluşturularak Antakya'nın uluslararası bir kongre merkezi olması sağlanabilir.

- Ayrıca şehirdeki konaklama kolaylıklarının geliştirilmesi ve hediyelik eşya satışı yapılan yeni alanların yaratılması da şehir ekonomisine katkı sağlayacağı için önemsenmelidir.

Hakem Değerlendirmesi: Dış bağımsız.

Yazar Katkıları: Çalışma Konsepti/Tasarım- H.D., Ö.N.; Veri Toplama- H.D., Ö.N.; Veri Analizi/Yorumlama- H.D., Ö.N.; Yazı Taslağ1- H.D., Ö.N.; İçeriğin Eleştirel İncelemesiH.D., Ö.N.; Son Onay ve Sorumluluk- H.D., Ö.N.

Çıkar Çatışması: Yazarlar çıkar çatışması bildirmemiştir.

Finansal Destek: Yazarlar bu çalışma için finansal destek almadığını beyan etmiştir.

Peer-review: Externally peer-reviewed.

Author Contributions: Conception/Design of Study- H.D., Ö.N.; Data Acquisition- H.D., Ö.N.; Data Analysis/Interpretation- H.D., Ö.N.; Drafting Manuscript- H.D., Ö.N.; Critical Revision of Manuscript- H.D., Ö.N.; Final Approval and Accountability- H.D., Ö.N. Conflict of Interest: The authors have no conflict of interest to declare.

Grant Support: The authors declared that this study has received no financial support.

\section{KAYNAKÇA/REFERENCES}

Antakya Belediyesi (2020). http://www.antakya.bel.tr/icerik/41/19/ habibi-neccar-camisi.aspx/. Son erişim17 Temmuz 2020.

Antakya Belediyesi (2021). http://www.antakya.bel.tr/icerik/16/6974/ kurtulus-caddesinde-tarihi-yapilarin-restorasyon-calismalariresmen-basladi--baskan-yilmaz-dunyanin-ilk-isiklandirilankurtulus-caddesini--tarihteki-ihtisamina-kavusturuyoruz.aspx, Son erişim 03.02.2021.

Antakya Kaymakamlığ1 (2020). http://www.antakya.gov.tr/kulturturizm. Son erişim: 12 Şubat 2021.

Antakya Ortodoks Kilisesi (2020). http://www.oodegr.com/tourkika/ ieroi_xwroi/naos_antakya.htm. Son erişim: 14 Kasım 2020.

Antakya Ticaret ve Sanayi Odası (2018). Antakya' da Yeme İçme İmkânı Sunan Mekân Sayısı.

Antakya Toplumcu Halk Gazetesi (2021). https://www.antakyagazetesi. com/hatay-buyuksehir-spor-kompleksinde/. Son erişim: 24 Şubat 2021.

Bahadır G. (2013). Hristiyanlığın Antakya'da şekillenmesi ve Habibi-i Neccar. Mustafa Kemal Üniversitesi Sosyal Bilimler Enstitüsü Dergisi, 10(23), 208-209. 
Başeymez, F. (2009). Çok kültürlülük açısından Hatay sosyolojik bir yaklaşım. Yüksek Lisans Tezi. Selçuk Üniversitesi Sosyal Bilimler Enstitüsü Sosyoloji Anabilim Dalı, Konya.

Cengiz, A. K. (2014). Eski Antakya evlerinin ikamet edenler tarafindan günümüzde kullanımı, Mustafa Kemal Üniversitesi Sosyal Bilimler Enstitüsü Dergisi, 25, 111-130.

Ceylan, S. ve Bulut, İ. (2019). Salda Gölü özel çevre koruma bölgesinde turizm baskıs1, koruma ve sürdürülebilirlik. Türk Coğrafya Dergisi, 73, 79-89. https://dergipark.org.tr/tr/download/article-file/910536

Çavuş, A. (2014). Trabzon'da doğa turizmi açısından değerlendirilmesi gereken turistik bir alan: Sera Gölü. Türk Coğrafya Dergisi, 63, 43-49. http://www.tcd.org.tr

Çelebi, Y. (1982). Bir grup eski Antakya evi. Türk Etnografya Dergisi, XVII, 163-201.

Çetin, B. (2012). Hatay'da kentleşmenin seyri (1940-2009) ve mekânsal dağılışı. Doğu Coğrafya Dergisi, 28, 259-282.

Çetin, B. ve Coşkun, M. (2020). Kültürel miras unsuru olan aba güreşine yönelik şekilsel ve işlevsel kültür bölgesi belirleme denemesi (Hatay). İstanbul Üniversitesi Coğrafya Dergisi, 40, 65-80.

Dayı, S. E. (2002). Hatay Devleti ve Hatay'ın Anavatan'a katılması. A.Ü. Türkiyat Araştırmaları Enstitüsü Dergisi, 19, 339.

Demir, A. (1996). Çağlar İçinde Antakya, İstanbul: Akbank Kültür ve Sanat Kitapları. (ss.13-15).

Dinç, Y. (2015). Antakya (Hatay) şehir coğrafyası, Yüksek Lisans Tezi. Mustafa Kemal Üniversitesi, Sosyal Bilimler Enstitüsü Coğrafya Anabilim Dal, Antakya.

Dinç, Y. ve Karagel, D. Ü. (2017). Antakya şehri'nin kuruluşu ve mekansal gelişimi. Arslan, F.(Ed.), Türkiye Coğrafyası Araştırmaları - Prof. Dr. Mesut Elibüyük'e Armağan (s. 571-597). Pegem Akademi, Ankara.

Doldur, H. (2011). One Of The Recreational Areas Near Istanbul: Polonezköy. NWSA -e-Journal of New World Sciences Academy, 6(4), 145-168, Article Number:4A0043.4A0043.

Doldur, H. (2014). Burhaniye - Bir Zeytincilik ve Sayfiye Yerleşmesi. İstanbul: Çantay Kitabevi.

Elka Fuar. (2021). http://www.elkafuar.com/project/4-hatay-tarimfuari/. Son erişim: 10 Şubat 2021.

Erdem, M. (2010). Doğu'nun kraliçesi Antakya. Antalya Rehberler Odasi Dergisi (ARO)DERGI), 1, 8-29.

Garipağaoğlu, N. ve Uzun, S. M. (2014). İzmit Körfezi kıyılarında kıyı alanı kullanımı. Türk Coğrafya Dergisi, 63, 9-22. http://www.tcd.org.tr

Hatay Büyükşehir Belediyesi Park Bahçe ve Yeşil Alanlar Dairesi Başkanlığı. (2018). Antakya Merkezine Yakın Parklar ve Mesire Alanları.

Hatay Gençlik ve Spor İl Müdürlügüu. (2020). Hatay Gençlik ve Spor İl Müdürlüğü.

Hatay İl Müftülüğü. (2017). Habib-i Neccar Cami Broşürü.

Hatay Valiliği. (2020). http://www.hatay.gov.tr/tibbi-ve-aromatikbitkiler-muzesi. Son erișim: 4 Şubat 2020.

Hatay Valiliği. (2021). http://www.hatay.gov.tr/hristiyanlarin-ilkmagara-mabedi. Son erişim 21 Şubat 2021.

Hatay Valiliği İl Kültür ve Turizm Müdürlüğü. (2018). Hatay Mutfă̆ UNESCO Gastronomi Şehri. Digital Art Reklam.
Hatay Valiliği İl Kültür ve Turizm Müdürlüğü-Hatay Turizm Konseyi. (2017a). Antakya Katolik Kilisesi. Barış, Kültür ve Hoşgörü Kenti Broşürü.

Hatay Valiliği İl Kültür ve Turizm Müdürlüğü- Hatay Turizm Konseyi. (2017b). Hatay Arkeoloji Müzesi Broşürü.

Ilgar, R. ve Şeran, Y. (2019). İstanbul ili, Bahçelievler ilçesinde park ve yeşil alan kullanımı. Türk Coğrafya Dergisi, 73, 7-16. https:// dergipark.org.tr/tr/download/article-file/847576

İstek, E. (2020). Seyyahların gözüyle Antakya şehri (10 - 19. yüzyıllar Aras1). Pamukkale Üniversitesi Sosyal Bilimler Enstitüsü Dergisi, 40, 227-246.

Kapan, K. (2016). Development and sustainability of the tourism in Lake Salda and its environs. Avcıkurt C., Dinu, M. S., Hacıoğlu, N., Efe, R., Soykan, A., Tetik, N. (Eds.), Global Issues and Trends in Tourism (ss.700-708). Sofia: St. Kliment Ohridski Univ. Press.

Kapan, K. (2018). Effects of tourism and recreation activities on economic structure: A case study on Antalya. Journal Of GeographyCografya Dergisi, 47-56.

Kartal, M. (2015). Gaziantep Şehrinde Rekreayonel Faaliyetlerin Dağıllışı. Basılmamış Yüksek Lisans Tezi, İstanbul Üniversitesi Sosyal Bilimler Enstitüsü, İstanbul.

Kaçmaz, M. (2005). Gelişmekte olan bir kış turizm merkezi İzmitKartepe, Ulusal Coğrafya Kongresi (Prof.Dr. İsmail Yalçılar Anısına), 29-30 Eylül, 547-555, İstanbul.

Kaçmaz, M. ve M. F. Döker. (2014). Turizm değerlerinin tanıtılması ve pazarlanmasında web-mobil tabanlı coğrafi bilgi sistemleri kullanımı" Coğrafya Araştırmalarında Coğrafi Bilgi Sistemleri Uygulamaları, Akköprü, E. ve Döker M. F. (Ed), (217-238), Pegem Akademi Yayınları.

Kaymaz, Ç. K. ve Özşahin, E. (2015). Coğrafya'da Yeni YaklaşımlarHarbiye Şelalesi (Defne-Hatay) Doğal Ortam Özellikleri ve Turizm Potansiyeli. İzmir Dokuz Eylül Üniversitesi Yayınları.

Meclis Kültür Merkezi. (2021). https://www.meclis.com.tr/kurumsal. Son erişim: 27 Aralık 2021.

Nesipoğlu, Ö. (2019). Antakya Şehrinde Rekreasyonel Faaliyetlerin Dağılışı. Basılmamış Yüksek Lisans Tezi. İstanbul Üniversitesi Sosyal Bilimler Enstitüsü Coğrafya Anabilim Dalı, İstanbul.

Özgüç. N. (2011). Turizm Coğrafyası Özellikler ve Bölgeler, İstanbul: Çantay Kitabevi.

Özgüç, N. (2017). Turizm Coğrafyası Özellikler ve Bölgeler, İstanbul: Çantay Kitabevi.

Sandal, E. K. ve Karademir, N. (2015). Ilıca (Kahramanmaraş) kaplıcalarında termal turizm odaklı rekreasyon faaliyetleri. Türk Coğrafya Dergisi, 64, 39-50. http://www.tcd.org.tr

Sargın, S. ve Dinç, Y. (2017). Kültür mirasının korunmasına yönelik mekânsal bir değerlendirme: eski (geleneksel) Antakya evlerinin fonksiyonel değişimi. Turkish Studies, 12(3), 477-506.

Sevil, T. (2012). Boş zaman ve rekreasyon: kavramlar ve özellikler” Boş Zaman ve Rekreasyon Yönetimi, Kocaekşi,S. (Ed), (2-25), Anadolu Üniversitesi Yayın. No:2497. http://docplayer.biz.tr/2013966-boszaman-ve-rekreasyon-yonetimi.html 
St. Pierre Anıt Müzesi. (2020). https://muze.gov.tr/muzedetay?DistId= MRK\&SectionId=STP0. Son erişim 16 Şubat 2020.

Şimşek, K. Y. (2012). Boş zaman ve rekreasyon endüstrisi” Boş Zaman ve Rekreasyon Yönetimi, Kocaekşi,S. (Ed), (26-52), Anadolu Üniversitesi Yayın. No: 2497. http://docplayer.biz.tr/2013966-boszaman-ve-rekreasyon-yonetimi.html

Timor, A. N. (2004). Ayvalık Bir Sayfiye Yerleşmesinin Gelişme Süreci. İstanbul: Çantay Kitabevi.
Tümertekin, E. (1968). Türkiye'de İç Göçler-Internal Migrations in Turkey, İstanbul Üniversitesi Coğrafya Enstitüsü Yayını.

Türk, H. ve Şahin, K. (2004). Antakya geleneksel yemek kültürü. Mustafa Kemal Üniversitesi Sosyal Bilimler Enstitüsü Dergisi, 2(2), 4-17.

Türkiye İller Ansiklopedisi. (2005). Antakya Tarihi 1(466-468). İstanbul: Milliyet Yayınları. 
